\title{
THE MEDIA AND POLITICS IN SPAIN: FROM DICTATORSHIP TO DEMOCRACY
}

\author{
Richard Gunther \\ Ohio State University \\ José Ramón Montero \\ Universidad Autónoma de Madrid \\ José Ignacio Wert \\ President and CEO, Demoscopia
}

WP núm. 176

Institut de Ciències Polítiques i Socials

Barcelona, 1999 
The Institut de Ciències Polítiques i Socials (ICPS) was created by the Universitat Autònoma de Barcelona and the Diputació de Barcelona in 1988. The ICPS is attached to the Universitat Autònoma de Barcelona.

These "Working Papers" -thought of as subject for discussion- are the result of research work in progress. Appearance in this series does not preclude further publication. This paper must not be reproduced without the author's licence.
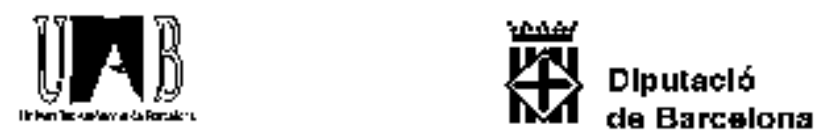

(C) Richard Gunther. José Ramón Montero. José Ignacio Wert

Design: Toni Viaplana

Printer: A.bis

c/ Leiva, 3, baixos. 08014 Barcelona

ISSN: 1133-8962

LD: B-50.278-99 
Few West European polities have undergone as many dramatic changes in the mid-20th century as Spain, and yet have succeeded in establishing stable, fully consolidated democratic systems. Spain inaugurated a fully democratic regime in 1931, the first in its long history. But it was extremely unstable, and collapsed in a bloody civil war just five years after its founding. An interlude of nearly four decades of authoritarian rule followed. A transition to democracy began in 1975, but in a very short period of time Spain was able to establish a stable, consolidated parliamentary monarchy indistinguishable in many ways from many other West European democracies. Thus, over the course of just six decades, Spain underwent an extraordinarily broad array of political experiences: from polarized, unstable democracy, to civil war, to authoritarian repression, to uncertain transition, to successful democratic consolidation.

Even this overview, as breathtaking as it may be, fails to do full justice to the scope of political, social, economic and cultural changes that Spain has undergone. Indeed, between Franco's death in 1975 and the mid 1980s its political system underwent two transitions: one from authoritarianism to democracy, the other from a highly centralized state to one in which considerable political power and fiscal resources have been devolved to autonomous regional governments. The magnitude of social-structural change has been equally impressive. From a situation of "semiperipheral" underdevelopment, Spain transformed itself into a country whose social and economic characteristics were comparable to those of other advanced West European societies in less than 20 years, as compared with the five or six decades required by most other European countries to develop economically.

The Spanish communications media have also undergone an extraordinary transformation, especially with regard to freedom of information. After nearly four decades of authoritarian rule which systematically suppressed the free flow of information, established a rigid system of censorship, and denied freedom of expression, a media structure emerged that is characterized by extraordinarily high levels of pluralism and complete liberty, solidly rooted in the democratic constitution of 1978. The structure of the mass-communications system was profoundly transformed by the shift in dominance from the print media to television as the public's principal source of information about politics. And the size and composition of media audiences has changed considerably, from a small attentive public to mass consumption, particularly of the broadcast media.

Given the multidimensional changes that Spain has experienced over the past six decades, it is an ideal laboratory for the examination of a wide variety of ways in which the communications media influence -and are affected by- politics. Three different periods in Spanish political history will be distinguished and examined separately, since the structure and political functions of the media were decidedly different from one period to another. The first is the dictatorship of Generalísimo Francisco Franco. We will focus our examination of this period on the structural constraints imposed on the media by this authoritarian regime, its efforts to use the media as a mechanism for solidifying its position in power, and, in the last decade of authoritarian rule, its tentative liberalization and relaxation of control over some of the media. The second period spans the transition to democracy, in which some important segments of the media played significant roles in establishing a new political regime and in disseminating to the general public new democratic values and behavioral norms. 
Finally, we explore some of the subtle and interactive ways in which the media affect electoral behavior in contemporary Spanish politics. Although this overview will cover significant media-related political developments up to the time of this writing, we shall focus the bulk of our analysis on the 1993 parliamentary election: this is to take advantage of a massive, multimethod study of the 1993 elections that we undertook as part of the Comparative National Elections Project, which includes a pre- and postelection panel survey of Spanish voters (using questionnaires including numerous items designed to tap into "media effects"), and parallel content analyses of political news coverage by television and newspapers ${ }^{1}$.

\section{FRANQUISMO: CONTROL OF THE MEDIA UNDER AN AUTHORITARIAN REGIME}

The political system established in 1939 by Francisco Franco was, along with the Salazar regime in neighboring Portugal, one of the longest-lasting dictatorships in Western Europe. It was the quintessential "authoritarian" regime (Linz 1975), characterized by limited and non-responsible political pluralism, political demobilization, a leader who exercised power within formally undefined but clearly recognizable limits, and the absence of an elaborated ideology. While these regime characteristics remained more or less constant, an overview of four decades of franquismo must make note of four distinct periods. From the victory in the civil war in 1939 until the mid 1940s, its totalitarian aspirations, its association with Hitler and Mussolini, and the recency of the war led to harsh repression, the presence of military officials among its governing elite, and efforts to establish a powerful quasi-fascist party. The regime during the 1950s was quite different: totalitarian aspirations abandoned, the party and its ideology were progressively watered down; and international isolation, stark poverty and an attempt to implement an autarchic economic development strategy had far-reaching effects on society. Over the following decade, however, the complete abandonment of economic autarchy contributed to one of the most rapid and sustained rates of economic growth in the world (7.3 percent between 1961 and 1973, second only to Japan -Gunther 1980, 63), transforming Spain into a relatively modern, affluent, urban society, and forging ever closer social and economic links with the rest of Europe. This socioeconomic modernization was accompanied by additional political changes, most significantly, the virtual disappearance of the official party as a significant political actor, and the making of most government decisions by a new, technocratic elite. These changes notwithstanding, the regime remained fully authoritarian throughout all four periods, and whatever "limited pluralism" did exist was restricted to those conservative-to-ultraconservative political factions, and to upper-stratum social and economic groups which supported the regime. Limited as these changes may have been, however, they had a significant impact on the communications media.

Totalitarian and authoritarian regimes do not differ greatly with regard to control of the communications media (Linz 1974, 1496-7). Despite the gradual disappearance of the regime's totalitarian features in the 1940s, its press restrictions did not change significantly. With some variations, these same policies were applied to radio and, beginning in the 1950s, to television. Only during the final ten years of franquismo were privately owned newspapers able to benefit from some liberalization, enabling them to play an important role in the crucial period immediately preceding the death of Franco and throughout the democratic transition. Strict government control of radio, television and the state-owned press, however, remained unchanged throughout the life of the regime. 


\section{The Press Law Of 1938: Censorship And Orders}

The basic framework for the franquist regime's communications policy was established by the Press Law of 1938. Although established on a "provisional" basis during the civil war, it remained in effect for nearly three decades. Its markedly totalitarian provisions were modeled after fascist legislation enacted in Italy in 1923 (Terrón 1981, 55-56). The law required state authorization for publications of any kind, and provided for the suspension of any publication without appeal. In addition, it enabled the state to intervene in the appointment and dismissal of newspaper managers and editors, even in the case of the privately owned press. Journalists were under especially strict control. Many were purged following the civil war, and all had to be officially registered with the government, belong to specific associations, and submit their reports for daily inspection to eliminate any information regarded as harmful to the dictatorship (Sinova 1989a; Abellán 1980). Not even advertising was exempt from this scrutiny. The criteria applied in this censorship process were inconsistent, however, changing in light of international circumstances and the current political proclivities of the regime. This introduced an element of arbitrariness, capriciousness and even silliness in actual practice ${ }^{2}$.

A second means by which the state sought to dominate the flow of information was by issuing "orders"-obligatory instructions to interpret news events in a particular way, or to avoid coverage of certain themes or events altogether. They were so detailed as to involve specific arguments to be included in editorials, the size of headlines, and even the position of photographs (Sinova 1989b, 266; Pizarroso 1989, 241-242). Press censorship and the issuance of orders remained in effect until well into the 1960s (Terrón 1981, 83-157).

The franquist regime created a substantial journalistic empire of its own, although, in contrast with some other non-democratic systems, it did not establish press or radio monopolies. The so-called Prensa del Movimiento (operated by the franquist National Movement, formerly the Falange) was created during the civil war out of publishing facilities confiscated from parties, trade unions and business firms that had supported the Republic. This made the state the principal newspaper publisher in Spain, and one of the most important in Europe, at least in terms of the total number of newspapers published (Montabes 1989, 24). By 1948, these state and Falange-operated enterprises owned a press agency, and were publishing 38 daily newspapers, 8 weekly and five monthly magazines. But despite the enormous statesubsidized infrastructure at their disposal, their circulation was significantly less than that of the private press. In 1950, for example, the state press published only about one third of the million daily newspapers sold, and its market share subsequently declined, culminating in nearly complete collapse in the final years of franquismo (Sinova 1989b, 270-1).

The diversity of the franquist coalition (which included falangistas, Catholics, monarchists, Carlist Traditionalists) largely explains the survival of private-sector journalistic enterprises, the most important of which were owned by Catholic or monarchist groups. At the end of the 1950s, the Catholic press included 34 newspapers (most of which were linked to the Asociación Católica Nacional de Propagandistas -ACNP- a lay organization that had exerted considerable influence in Spanish political life since 1909), with an average daily circulation of 340,000. The ACNP controlled a press agency and five newspapers, among them Ya, whose daily circulation exceeded 100,000 (Hermet 1985, 195-199; García Escudero 1984). Various monarchist groups published five newspapers, the most important of which was 
$A B C$, whose circulation exceeded 200,000 daily (Iglesias 1980). Even though there was a large number of private-sector publications, the controls imposed on the press by the authoritarian regime precluded the development of a diversity of ideological or political orientations. These newspapers could only differ from one another with regard to secondary or marginal issues, always within the overall framework of continued support for the regime. Accordingly, in a 1964 survey $^{3}, 49$ percent of newspaper readers in Madrid thought that all newspapers had the same political orientation, and 65 percent claimed not to believe the news they read (IOP 1965b, 196).

Despite the large number of newspapers, their aggregate circulation was remarkably low. A comparison with other Western countries in 1964 showed that the number of newspapers sold per thousand persons in Spain (71) was not only the lowest among the 16 countries surveyed, but it was far behind even the next-lowest country in this survey, Italy (where newspaper sales averaged 123 per thousand). By way of comparison, in France, the United States, West Germany, Japan and Britain the number of daily newspapers sold per thousand persons ranged between 242 and 573 (IOP 1964, 17). The uniformity and resulting monotony of domestic news coverage alienated the public from the print media, and help to explain the low levels of both newspaper readership and trust in the press (Sinova 1989a, 13 and 17; and 1989b, 270).

Newspapers devoted more space to commercial advertisements than to any other type of material (IOP 1964, and 1965a, 147). "Political news" was limited to official press releases concerning ceremonies, appointments and inaugurations, written in a rhetorical style charged with triumphalism, adulation and sectarianism. In coverage of local news, some minor criticisms were tolerated, although these sometimes resulted in conflicts with the local authorities and the imposition of sanctions against the offending newspaper. In sharp contrast, coverage of international news was remarkably balanced, and was often so extensive as to dominate the news segments of the newspapers (Beneyto 1965, 22; and Pizarroso 1989, 248). Openness and balance in coverage of international news was especially notable among those newspapers which could afford to have their own foreign correspondents.

\section{The Press Law Of 1966: Controlled Liberalization}

Several developments came together in the mid 1960s to create pressures for the enactment of a new Press Law. For some time, the Catholic factions within the regime had favored a less rigid and bureaucratic system of control (Terrón 1981, 135-53; Tusell 1984, 344-59). Their position within the franquist coalition was strengthened after 1957 by the influx of Opus Dei technocrats into the government and by repudiation of the Falangist economic policies of economic autarchy. Economic liberalization and the more open, international orientation of these largely apolitical technocrats substantially undermined support for the heavy-handed, nationalistic propaganda long disseminated by the Movimiento and imposed by censors, and created conditions favorable to an increased liberalization of the press.

The most decisive steps towards press liberalization were taken by Manual Fraga Iribarne, who assumed responsibility for regulation of the communications media in 1962. At first, Fraga merely relaxed the most repressive aspects of censorship and the issuance of "orders", but left the Press Law of 1938 unreformed. These modest steps made possible a certain intellectual liberalization within university circles which subsequently spread to the print media. 
The Press Law of 1966 (commonly referred to as the Ley Fraga) carried this process much further. Its most important innovations were the elimination of prior censorship and relaxation of direct controls on newspapers and publishing houses. Publishing firms were also allowed to freely appoint their own managers and editors (although their job security was made conditional on their publications not incurring three or more formal sanctions a year). The state also retained the right to punish publishers for what it considered violations of ill-defined norms, whose interpretation was solely at its own discretion. This led to the emergence of new forms of self-censorship which, in combination with state-imposed sanctions based on arbitrary and poorly defined criteria, led to confusion and occasionally harsh repression, including heavy fines, confiscation of newspaper and magazine issues, and, on occasion, the closure of offending publishing houses. Thus, this reform was always regarded as an apertura (an opening-up, or partial liberalization) vis-à-vis the heavier and more narrow constraints of the preceding era, rather than the establishment of the kind of press freedoms and regulations characteristic of Western democracies ${ }^{4}$.

The most significant impact of the 1966 Press Law involved the quality of reporting on political news. A certain ideological differentiation was allowed among private-sector periodicals, particularly magazines, stimulating a rise in their modest levels of circulation ${ }^{5}$. Public confidence in the press increased significantly: between 1960 and 1973, the share of Spaniards polled in surveys who expressed confidence in the press rose from 33 percent to 47 percent, while those expressing attitudes of distrust fell from 65 percent of those surveyed to 30 percent (IOP 1975a, 305). State-run publications, however, which remained subject to strict government vigilance and rigorous political control, did not evolve in this manner. As a result of their continuing monotony and lack of credibility, their circulations declined precipitously in the mid 1970s (Montabes 1989, 38 and 46).

The Ley Fraga played a significant role in undermining franquismo. While it did not establish freedom of the press, it did increase freedom of expression which, in turn, expanded the audience of the print media, and stimulated greater popular interest in the news (Sinova 1989b, 270). Some newspapers and magazines, especially those based in Madrid and Barcelona, took considerable advantage of increased government tolerance and the greater fluidity of Spain's rapidly modernizing society by markedly broadening and liberalizing their news coverage, including reports on formerly taboo subjects such as strikes, student protests, and critical alternatives to policies adopted by the government (Barrera 1995, 107 8). As Terrón has written, "Newspapers began... to perform a moderately critical role, and magazines were converted in many instances into outlets for political opinions and ideologies distinct from and sometimes contrary to those of the regime" $(1981,217)$.

\section{Radio and Television: Continuing News Monopoly}

Like the press, radio emerged from the civil war as an instrument of government propaganda. The franquist Nuevo Estado seized pro-Republican broadcasting stations, while allowing many other networks and stations to remain in the hands of private business enterprises. As with the print media, a 1939 decree (which would remain in effect for the next 38 years) established a system of prior censorship for all commercial radio broadcasts. Coverage of general news, both national and international, was reserved exclusively for the official network, Radio Nacional de España (RNE). Private-sector broadcasters were required to retransmit RNE news broadcasts twice each day. In general, radio did not undergo the same 
liberalization that the print media enjoyed under Fraga's reforms of the mid 1960s.

The structure of radio broadcasting, however, did change considerably, mainly to consolidate and regulate the explosive and seemingly chaotic expansion of the 1960s. In 1963, there were 471 broadcasting stations throughout the country (over four times the number of two decades earlier), 71 percent of which lacked the requisite broadcasting licenses (Multigner 1989, 274-5). Under Manuel Fraga, the Ministry of Information and Tourism reversed this proliferation of stations, reducing their total number to about 200, and grouping them into six broadcasting networks. About half of these stations were staterun, and the other half belonged to the COPE network (operated by the Catholic Church) and various commercial chains, the most important of which was the Sociedad Española de Radiodifusión (SER) (IOP 1970, 169-70).

Throughout the franquist era, radio coverage of politically relevant developments was subjected to severe restrictions. Although the practice of prior censorship was phased out, private radio networks were prohibited from broadcasting their own news programs until after Franco's death and the onset of the democratic transition. Spaniards thus had no alternative but to receive the news through the official broadcasts of RNE. And in describing those broadcasts, González Seara writes:

aside from the pompous style of the reporters, the news was broadcast in a solemn tone such that the description of [Franco's] appearance at an inaugural ceremony was read almost like a recital from Shakespeare... The news was full of exaltations of the patriotic virtues and the progress of our society, all according to orders $(1972,781)$.

During the two decades preceding the transition to democracy, radio audiences shrank considerably, and radio was rapidly overtaken by television as the principal electronic-communications medium. While 86 percent of Madrid residents had reported in a mid-1960s survey that they listened to the radio every day, by 1974 only 33 percent of nationwide survey respondents claimed to listen to the radio every day or several times a week (IOP 1975a, 308-15). Thus, radio was not in position to play a significant role in liberalizing Spanish society or initiating the political transition.

Regular television broadcasts began in 1956. Less than two decades later, over 90 percent of all Spaniards were regular viewers (see Table 1). Television quickly overtook radio as the principal entertainment medium, and surpassed the print media as the principal source of political news, especially with regard to international political developments. As recently as the mid 1960s (see Table 2), more people had relied on the press than television as a news source. But by 1973, this situation was completely reversed. A poll conducted in that year revealed that 31 percent of Spaniards regularly read a newspaper, 42 percent listened to radio, and 75 percent watched television every day (IOP 1975b, 272; also see IOP 1976, 401). Given some evidence that survey respondents exaggerate the frequency with which they read newspapers, it is probable that the gap separating television from the other news sources is even greater (Wert 1976, 129-35), and that, for a large segment of the Spanish population, television had become the only news source. Regarding television as a valuable tool for socialization and propaganda, the Ministry of Information extended the reach of television even to those not owning sets by setting up "tele-clubs" in rural and suburban areas. By 1972, these clubs had attracted over 800,000 members (de Bergareche, et al, $1976,1056)$.

Government control over the new medium was tighter and more direct than over radio and the 
press, and television news broadcasts functioned as a propagandistic tool at the service of the regime until after Franco's death in November 1975. González Seara (1972, 783-4) characterizes the nature of television news broadcasts as dominated by

"a Manichean conceptualization of the universe characterized by generally evil and negative developments abroad and peace and progress at home... An example of how Televisión Española presented the news can be seen the sequence of items covered in its program 24 Hours: killings in Vietnam, massacres in Dacca, protests in Warsaw, disturbances in Belfast, students stoning the police in Milan, layoffs at Volkswagen, accusations against the Minister of the Interior in the French National Assembly, parliamentary crisis in Italy; then, [following this string of foreign disasters], the opening of a new hotel in the Balearic Islands, the closing ceremony of the Auto Show in Barcelona, the gala banquet for recipients of national cinema and television awards, a speech before the Chamber of Commerce... and, to conclude, a local festival, accompanied by cheerful bagpipe music".

Despite the authoritarian regime's more direct control and heavy-handed propagandistic manipulation of television than of any other medium, Spaniards regarded television as the most trustworthy medium, and the best source of news. Repeated surveys undertaken in the 1960s and 1970s revealed that about half of those polled regarded television as the medium which provided the most complete and interesting news, as compared with 19 percent who preferred the print media and 15 percent who preferred radio broadcasts (IOP 1967, 204, 1975b, 273, and 1976, 409). Two thirds of those interviewed in a 1973 survey said that they trusted television "a great deal" or substantially, as compared with only 57 percent who similarly evaluated radio and 47 percent who rated newspapers as trustworthy (IOP 1975b, 274). This striking inconsistency between the reality of state manipulation of television, on the one hand, and widespread feelings of trust and confidence in that same medium, on the other, constitutes a puzzle to which we shall return later.

\section{THE MEDIA AND AUTHORITARIANISM: AN ASSESSMENT}

Throughout the first three decades of franquist authoritarianism, the impact of the media on politics was relatively uniform and completely supportive of the regime. The regime regarded the communications media as a propaganda tool in the service of the state (Sinova 1989a, 276-7), irrespective of whether a particular medium was state property or privately owned. But in accord with the basic nature of the authoritarian Franco regime, the primary impact of media control was to secure the passive acquiescence of the Spanish population, rather than to resocialize the citizenry into active participatory roles. In contrast with the role of the media under a totalitarian regime -whose objective is to mobilize the population in an effort to remake society in accord with an official ideology- the non-revolutionary (indeed, reactionary) political and social objectives of franquismo meant that the overriding political function of its communications policy was to demobilize and depoliticize Spanish society. This was particularly true of the period following the end of the Second World War ${ }^{6}$. Regime maintenance was facilitated by communications policies which effectively bored most Spaniards into passivity and acquiescence, and deprived them of stimuli that might have triggered political mobilization. The dissemination of apolitical, antipolitical and antidemocratic messages was of particular political significance during the processes of rapid social modernization that occurred beginning in the early $1960 \mathrm{~s}$. In effect, it helped to postpone the political mobilization of a population whose levels of literacy, urbanization and education were rising rapidly. 
While we lack sufficient empirical evidence concerning the linkage between media consumption habits and political values during the 1960 s and early 1970 s to substantiate claims of causality, it is important to note that these characteristics of the Spanish media under franquismo are entirely compatible with fundamental characteristics of Spanish political culture at that time. The absence of a clearly defined regime ideology and mobilizational intentions meant that no identifiably "franquist" political culture would be inculcated into more than a small minority of the population, but a marked apoliticism and cynicism towards "politics" was widespread (Montero and Torcal 1990). Studies conducted in the late 1960s indicated that most of the population (between 50 and 55 percent) had only the most simplistic political attitudes; they looked on politics with distrust and fear; they responded to political stimuli in a defensive and authoritarian fashion; and they would eventually emerge as a passive segment of the electorate (López Pintor 1982, 78-80; López Pina and Aranguren 1976, 63-72). Alongside this majority segment of the population were two more politically aware minority groups. About 15 percent of the population actively identified with the Franco regime, and shared its authoritarian values, its dogmatism and its intolerance. At the other extreme, about one quarter to one third of the population held entirely different values and were alienated from the regime.

In the absence of survey data from the 1960s which would provide direct evidence concerning the linkage between media exposure and basic attitudes towards politics, a comparison between the passive majority and those minority sectors of Spanish society that were active in opposition suggests that the nature of this relationship is interactive with other social and political determinants of mass behavior. Beginning in 1956, but especially in the 1960s, workers in certain parts of Spain and university students would occasionally mount protest demonstrations. These were especially frequent and massive in the late 1960s. Maravall's excellent study (1978) of political activists in the late 1960s revealed that, although workers and students occupied very different positions in Spain's stratification system, they shared one attribute: they were immersed in sub-cultures which exposed individuals to information and values incompatible with the official doctrines of the regime, and which served as stimuli for protest activity. Both militant workers in heavy-industrial centers in the north of Spain and students in university communities (within which several varieties of Marxism flourished and often represented the dominant ideological orientation) were highly atypical of most Spaniards insofar as they were frequently confronted with flows of information which undercut the credibility of franquist propaganda. The majority of Spaniards residing outside of these subcultural milieux, on the other hand, were not exposed to this conflicting information, and were therefore predisposed to behave in conformity with the cues disseminated by the regime.

A broader implication of these findings is that the type and basic characteristics of the nondemocratic system may have an important impact on the effectiveness of state control of political information. Both totalitarian and authoritarian regimes dominate the mass communications media, and the two types of regime are indistinguishable from one another with regard to their use of the media as channels for propaganda. Authoritarian regimes, however, are characterized by a shallow penetration into the interstices of society, thus allowing significant subcultures to retain considerable autonomy. We hypothesize that within those pockets of society independent flows of information may be so incompatible with the regime's messages that even the minimal objective of deterring protest behavior may be out of reach. The greater the penetration by a nondemocratic regime into its society, and the fewer the pockets of 
society with subcultural autonomy, the more likely the regime's messages will go uncontested, and therefore that it will effectively discourage protest or, perhaps, to resocialize the population.

The basic thrust of the messages the regime sought to disseminate were also increasingly inconsistent with the realities of Spain and of Western Europe of the 1960s and 70s. Franco's efforts to resurrect traditionalist values and marry them to a corporatist-authoritarian political structure were doomed to failure by the country's substantial and rapid modernization in the 1960s and 70s. The passivity, deference to authority, narrow religiosity and anti-liberalism which were central components of franquist propaganda simply did not ring true in a modern, urbanized society set within the context of a stable, prosperous, democratic Western Europe. This inconsistency was made highly visible to many Spaniards as the result of the internationalization of the Spanish economy beginning in the late 1950s. The temporary migration of 2 million Spanish workers abroad (most of them to affluent, peaceful, democratic West European countries), and the annual influx of 40 million tourists, almost all of them from rich democracies, exposed many Spaniards to the values of democracy, provided many of them with models for emulation, and destroyed the credibility of the regime's anachronistic propaganda. All of these factors exposed Spaniards to flows of information that were either internally inconsistent, or simply did not fit with easily observable reality.

This is not to say that the regime's propaganda had no lasting impact on Spanish society. While the regime completely failed to institutionalize a significant antidemocratic, right-wing party or movement which could survive in the democratic era ${ }^{7}$, depoliticization and cynicism towards competitive-party politics -central themes disseminated by Franco's communications media, and by the formal "civics" training imparted by the severely underfunded and underdeveloped education system- represent distinguishing characteristics of Spain's political culture today. Since the end of the 1980s, levels of interest in politics have consistently been among the lowest of all European countries. A 1993 survey revealed that only 4 percent of the Spanish electorate claimed to be very interested in politics, with another 21 percent somewhat interested in politics, and only 9 percent said that they discussed politics "often" with their friends ${ }^{8}$. The frequency of reading about politics in the newspapers and in news magazines was also substantially lower than is typical of other industrialized societies (as we shall see later in this chapter), as is turnout at general elections. While the overall level of support for democracy is as high as the average among European Union countries (Montero and Gunther, 1994), levels of party identification are the lowest of any West European country, and attitudes of cynicism towards parties and politicians are rather widespread. Surveys have shown that, when asked to describe their feelings about politics, most Spaniards use terms such as "distrust", "indifference" and "boredom", while their own relationships with the political system are characterized by a lack of subjective competence and inefficacy (Montero and Torcal 1990; and Montero and Gunther 1994). This suggests that one unanticipated legacy of franquismo was a cluster of political cultural attributes -political indifference, cynicism and indifference- that has somewhat diminished the quality of Spanish democracy through at least the 1980s (Montero, Gunther and Torcal 1998).

\section{The Roots of Change}

The incompatibility between Fraga's press liberalization and a continuation of authoritarian rule had become increasingly apparent by the early 1970s. A growing segment of newspapers and magazines 
took advantage of Fraga's partial liberalization by expanding the informational content of their news reporting, adopting a new language of cautious (sometimes coded) political discourse, reporting on the increasingly frequent internal conflicts and external developments that weakened the regime's hold on power (Maravall and Santamaría 1989, 192-6). Some private radio stations behaved similarly, breaking the news monopoly that had been granted to the official RNE (Martínez de las Heras 1989, 430).

One particularly interesting and politically significant practice was to use international news events as vehicles for the education of Spaniards about the workings and merits of democratic politics, and prospects for political change ${ }^{9}$. While clashes between political ideologies, or the basic nature of parliamentary democracy could not be openly discussed with specific reference to Spain, press coverage of elections or parliamentary struggles in Italy, France or Britain was relatively free from censorship, and thus could be used to teach Spaniards about the underpinnings of democratic politics. The higher levels of affluence and long traditions of democratic stability of Spain's European neighbors enhanced their attractiveness as models for emulation (López Pintor 1974; Moral 1989). One indirect measure of this "vicarious learning" process can be seen in the findings of a survey conducted in 1973, prior to the death of Franco, which revealed that 29 percent of those polled stated that they identified themselves with one of the major West European "political families" -Christian democratic, liberal, social-democratic, socialist or communist (Linz et al 1981, 14). Three years later (but still one year before the first democratic elections), that figure had risen to 58 percent (Jiménez Blanco et al 1977, 121). Even larger numbers of Spaniards were able to place themselves and various Spanish political actors on the left-right scale, based upon terminology and concepts that had been banned from Spanish political discourse over the previous decades. In two polls conducted in 1976, seven out of ten were able to do so.

The scope and pace of fundamental changes in political orientations of Spain's citizenry are impressive, and challenge some common notions about political socialization. Rather than conforming to the conventional wisdom that basic attitudes towards democracy, political parties, democratic institutions, etc., are largely fixed by early adulthood and are not easily amenable to pressures for change, we see among the Spanish citizenry fundamental shifts occurring in a remarkably short period of time. Between 1966 and 1974, for example, the percentage of Spaniards stating in public opinion surveys that they favored freedom of expression increased from 40 to 74 percent (IOP 1967, 222, and Gómez-Reino, Orizo and Vila 1976, 1168). As can be seen in Table 3, a number of other attitudes incompatible with the basic tenets of franquismo -regarding freedom of religion and trade-union affiliation, in particular- were also widespread among Spaniards one before Franco's death. Similarly, in May 1976, after a decade of press liberalization but one year prior to Spain's first democratic elections, fully 78 percent of those polled favored the popular election of government officials, up from just 35 percent in 1966 (López Pintor 1982, 84). Since the greatest shift was from the "don't know" category in 1966 to support for democracy a decade later, this resocialization function appears to have primarily involved the inculcation of democratic attitudes into a population whose political opinions were inchoate, poorly anchored and sometimes contradictory ${ }^{10}$.

Since the formal socialization imparted by the regime through its control of the educational system remained antidemocratic until the end, the principal sources of pro-democratic socialization (except for relatively affluent elites and those Spanish workers who migrated abroad for temporary employment) were messages and information disseminated by the media. Liberalization of the press thus appears to have contributed to the democratic transition by facilitating a significant (but incomplete) transformation 
of Spanish political culture. Fundamental democratic principles were disseminated through increasingly free and critical news reporting and journalistic commentaries, and through the appearance in the press of intellectuals, representatives of clandestine parties and trade unions or of the "alegal" or tolerated opposition. Greater media pluralism also contributed to democratization over the long term by delegitimizing the franquist regime, by providing a platform for the discussion of alternatives to franquismo, and by serving as the principal channel for the resocialization of "the attentive public". A "reemergence" of civil society, featuring much greater ideological pluralism, also resulted (López Pintor 1982, 90). To some extent, this "reemergence" was facilitated by the preservation and intergenerational transmission of democratic attitudes which predated the Franco regime (Maravall 1978), but the public articulation of these values in the press during the late 1960s and early 1970s appears to have significantly reinforced this attitudinal contagion and crystallization.

\section{DEMOCRATIZATION}

During the first six months after Franco's death, the government of Spain was led by the ultraconservative Carlos Arias Navarro. This was a time of extreme political and social tensions, especially between late January and early May, 1976. During this period, the regime maintained its rigid control over television news broadcasts and, to a lesser degree, over radio, but the print media (sporadic government crackdowns notwithstanding) enjoyed considerable freedom regarding both news coverage and the expression of editorial and op-ed opinions. While there was no change in the legal statutes which regulated the media during this period, those statutes were interpreted more permissively. Overall, this period should be regarded as merely an extension of that initiated with Fraga's press law.

By this time, only a handful of publications and a few dozen journalists had assumed clearly democratic positions. Other journalists were divided between fervent, sycophantic supporters of franquismo, and a much larger number of those who were characterized by "complicity, docility, indifference and passivity" vis-à-vis the regime (Santos 1995, 57). The press of the Movimiento, the extreme-right press, and the ultraconservative monarchist daily $A B C$ remained hostile to political change.

Within two years, however, the print media had been transformed, with nearly all of the press supporting democratization (Aguilar 1982). This transformation was facilitated by the disappearance from newsrooms of the older generation of editors (Santos 1995, 60-1), and by the appearance of new newspapers and magazines. By far the most important of these was the daily El País which began publication in May, 1976, and served as a vehicle for disseminating the opinions of progressive reformers within the regime, as well as those of representatives of the moderate opposition groups (liberals, social democrats and Christian Democrats). Its principal stockholders included representatives of all of the "political families" which would govern during the transition to democracy. From its very first issue, it was clear that El País represented an important change in Spanish journalism. It functioned as if there were no restrictions on freedom of the press. With regard to both its news coverage and its editorial opinions, it behaved like any other West European news daily, without recourse to the tricks others employed to sidestep the obstacles presented by the Press Law. El País appeared at a key moment in Spain's political development, when it became clear that the political option presented by Arias Navarro had failed to meet even the most minimal reformist demands. It quickly became the country's leading newspaper and a model 
for emulation by other dailies (Imbert 1988), particularly with regard to its commitment to democratization and its dissemination of a broad array of political opinions. The breech opened by El País in the regime's system of information control helped to accelerate the pace of political and media change (Gaitán 1992; and Cebrián 1980).

It was not until Adolfo Suárez was appointed prime minister in July 1976 that one could speak of a true process of political transition ${ }^{11}$. Indeed, the first significant act of the democratic era was enactment of the Law for Political Reform in the autumn of 1976. This law -the centerpiece of the regime-transition strategy formulated by Suárez and his collaborators- established an array of basic democratic freedoms, called for free democratic elections within six months, and initiated a series of sweeping changes regarding the structure and control of the communications media. During this early phase of the transition to democracy, many segments of the media served as conduits for information about the strategy for political change being implemented by the reformist Suárez government, as well as platforms for the articulation of political demands by newly emerging political and trade union organizations ${ }^{12}$. Once the transition was well under way and the institutions and behavioral norms of the new democratic regime began to take shape, the communications media began to play a second crucial function: to explain to the general public the new rules of the game and the basic values and orientations underpinning democratic politics, thereby completing the political resocialization that had been set in motion a decade earlier.

These changes in the political orientations and behavior of the media were accompanied by significant structural changes.

Television: By the end of the franquist era television was by far the most popular communications medium, as well as the most heavily subjected to government control. Prior to the first democratic election in June 1977, there was no change in the structural relationship between TVE and the government: its two channels remained under the direct control of the Ministry of Information, and the content of news coverage was subjected to political oversight down to its finest details. In terms of the substantive biases of television coverage, however, there was a fundamental change following Suárez's appointment as prime minister: television was transformed into a voice supporting processes of democratic transformation. Of particular significance was that it was used as a medium through which the nature of political change could be explained to newly enfranchised citizens, and through which newly legalized political parties could appeal to voters.

The fact that the liberalization of this period did not include a reform of the structural relationship between the government and TVE, however, led to predictable political controversies: questions regarding the partisan objectivity of the state's television network soon became salient. Rival parties complained that TVE tilted its news coverage in favor of Aldofo Suárez's Unión de Centro Democrático during the 1977 election campaign. The first institutional response was the creation, following the 1977 elections, of a Council of Vigilance and Control, composed of members of parliament. It was practically inoperative, however, during its brief existence. This was followed by much more substantial institutional reforms enacted through the Organic Law of 1980. As we shall see, those structural changes had a substantial impact on the objectivity and balance of political coverage through the public broadcasting media, but did not put an end to opposition party complaints about partisan bias. 
The Press: Contrary to all expectations, the establishment of full freedom of expression did not lead to an increase in newspaper readership. To be sure, the total number of newspapers in circulation increased by about 30 percent (Wert 1980, 40-41), but the expectation that the winds of freedom would scatter the seeds of interest in the press and lead to a broadening of readership was not realized: in 1974, 32 percent of Spaniards reported that they read newspapers every day; by 1979, that figure had fallen to 29 percent (Wert 1976, 119; and 1980, 39). In other respects, however, the press evolved in a manner that one might have anticipated following the demise of an authoritarian regime: readers shifted to the emerging democratic press, and those newspapers which had supported the franquist regime virtually disappeared.

During the transition (1976-79), a number of periodicals reflecting a variety of political orientations came into existence. Within a few months of the birth of El País, a new newspaper, Diario 16, was created by the publishing group which produced the pro-democratic news magazine Cambio 16. This new daily provided a liberal ${ }^{13}$ counterpoint to the social-democratic El País. Similar initiatives were launched in Barcelona and some other provinces, leading to a substantial expansion of the democratic press, previously represented by a handful of publications, including Informaciones, Ya and a few others. The principal impact on the size of the reading audience, however, was limited. Much of the increase in circulation reflected the reading of multiple daily papers by an informed and interested minority of the population. More importantly, the new publications crowded established newspapers out of the market. Three Madrid dailies, for example, had played important roles in disseminating democratic viewpoints during the final years of franquismo: the morning newspapers Ya (published by the Editorial Católica) and Nuevo Diario, and the evening daily Informaciones. These newspapers suffered such severe financial difficulties that the latter two disappeared ${ }^{14}$, while $Y a$ (whose potential readership has continued to shrink as a result of the substantial secularization of Spanish society over the past two decades -see Montero, 1993) fell from its position as the most widely read Madrid daily to last place in terms of circulation (Edo 1994, 83-95). A general indicator of this process can be seen in the evolution of the total number of newspapers in existence at various stages in the transition: when Franco died, there were 115 newspapers; within two years, this figure had risen to 143, as new publications flooded into the market; but by 1979 , following the financial collapse of many uncompetitive newspapers, the total was reduced to 103 (Wert 1980, 34-5), and by 1989 it had fallen to 84 (Montabes 1994, 66). Meanwhile, the newspaper with the highest circulation in 1979 was one that did not even exist four years earlier, El País.

Magazines: In the final years of the franquist regime, magazines had been the medium through which political criticism could be most easily channeled. Given their more limited circulation, less rigorous state oversight was exercised than with regard to daily newspapers, and they were in a better position to articulate democratic values and provide a public forum for once clandestine opposition groups (Sunkel 1994, 169). During the course of the transition era, however, daily newspapers began to enjoy the same freedom from government control, and news magazines found themselves increasingly unable to compete for adequate shares in the print-media market. The major national newspapers adopted a style that posed a direct competitive threat, insofar as their high-quality, general-information format provided more national and international news than most avid readers could keep up with on a daily basis, and their extensive, glossy Sunday supplements left little room for competitors. Thus, paradoxically, such magazines as Cuadernos para el Diálogo and Triunfo, which had valiantly struggled under franquismo to keep alive the flame of democracy, entered into irreversible financial crises just as their goal was achieved ${ }^{15}$. 
The only successful entries into this tough market were hybrid publications that mixed political news coverage and commentary with sex (sometimes pornographic) and sensationalism. The most successful of these odd publications was Interviú, born in 1977, which juxtaposes in-depth political interviews and provocative photos of attractive, nude women, and whose circulation in 1979 reached three million copies each week (Wert 1980, 42-3). But even this publication declined in circulation over the following decades, falling to just over 1 million readers by 1994 (Anuario El País 1995, p. 202). Other news magazines have suffered more serious declines in circulation and political influence. In its better days, Cambio 16 (with over 170,000 weekly sales at its peak in 1981) had a devoted following among the politically informed and active sectors of the population. In the early stages of the transition period, it had played an important communication function within the politically informed strata of Spanish society. By the mid 1990s, however, it had undergone a serious decline in circulation (down to just over 90,000 in $1993)^{16}$, prestige and influence.

News magazines, which had played an important opposition role under the Franco dictatorship, became much less important politically after freedom of the press was secured. Among respondents in our 1993 Comparative National Elections Project (CNEP) survey, 87 percent said that they read news magazines less than once a week (23 percent) or never (64 percent). With these small readership levels, their political impact is most likely quite limited.

Radio: In this same period, radio was undergoing its own transformation. With the substantial growth of television during the 1960s and 1970s, both its share of the media market and its role in Spanish society were on the wane. During the transition, however, radio underwent a significant rebirth as a source of news. This was facilitated by the fact that government oversight, control and censorship of radio had always been more relaxed than for television, in part because of the existence of a sizable private broadcasting sector.

With the onset of the transition in 1976, the legal framework regulating radio was relaxed (Santos 1995, 133-6). First, private radio stations were released from the obligation to retransmit the state's news broadcasts. By 1977, private radio networks were allowed to develop their own news services, completely free of state control. The gradual expansion of their news-reporting activities, which began with news coverage of sports and non-political events (train wrecks, etc.), spread to reporting about local news developments, and eventually included coverage of national and international political news. The style and format of news broadcasts also changed. In contrast with the solemnity and excessive restraint of RNE news broadcasts, private radio (led by the SER network) initiated a more informal and less irritating style, and, unconstrained by the kinds of rigidity in scheduling that limited television's flexibility, more responsive to the immediacy of news developments. Subsequently, even state radio networks were urged to "keep up with the competition" by taking on a more independent role as a source of information. Thus, a liberalization of the public sector of radio began, and stations soon exhibited substantially greater pluralism and less pro-government bias than was characteristic of state-run television, even prior to enactment of a Statute which institutionalized external oversight of public radio designed to guarantee its pluralism and objectivity.

This qualitative change was accompanied by a rapid increase in the size of radio audiences. The segment of the population listening to radio news programs increased from only 7 percent in the final 
years of franquismo to 20 percent during the transition (Wert 1976, 126-7). And audiences for all kinds of radio programs also expanded considerably, from 35 percent of the population in 1973 to 50 percent in 1979 (Wert 1980, 49-51).

The Media and Politics During the Transition. In general, the transition was a period of effervescence in the media -of political involvement and more real change in the structure and behavior of the media than might be suggested by the relatively modest reforms in their regulatory framework. They adapted to the newly emerging democracy, but they also played a role in contributing to that process of political change.

Perhaps the most important political function performed by the communications media during the period of the transition was to help to resocialize Spain's adult population to acknowledge the legitimacy of the new regime and to internalize fundamental norms of democratic behavior. Given the shallow penetration of party organizations into Spanish society, coupled with the weakness or absence of other secondary organizations with explicit ties to political parties, the media served as the principal channels for the flow to citizens of partisan cues, democratic values, political information and norms of tolerance of differing political views. Television, radio and the press helped to teach these norms and values largely by example: they were the most visible arenas within which individuals could debate and disagree with one another civilly. This informal and indirect dissemination of pluralistic attitudes and norms of tolerance undermined many of the central tenets of franquist political culture, among them, the notions that liberal pluralism and individual freedom inevitably culminate in destructive conflict, and that a single enlightened ruler could somehow translate absolute truths into policies that were in the interest of all of society. The media also placed a variety of important reforms on the agenda, and served as forums for political dialogue, which were necessary for the development and eventual institutionalization of political pluralism. In general, the media contributed to democracy by spreading the belief that a continuation of franquismo was untenable, and that democracy was the only viable alternative to that discredited political system. They presented a realistic and attractive model for the exit from authoritarianism based on pacts and transactions, on gradualism, and on the adaptability of the demands of political actors and social forces to greatly altered circumstances (Wert 1986, 168).

The media's positive role notwithstanding, we must nonetheless remain skeptical about the exaggerated claims commonly made by journalists and broadcasters concerning their heroic roles as the "Paladins of liberty" in this process of political transformation (e.g., in Maxwell 1983). They were merely one set of actors among many who contributed to the eventual success of the democratization of Spain, and their principal function was to channel to the mass public messages that originated among political elites.

\section{THE MEDIA AND POLITICS TODAY}

The beginning of the current era of Spanish politics dates from 1982, by which time the transition had been completed and Spanish democracy consolidated (Gunther 1992a; and Gunther, Puhle and Diamandouros 1995). In this period of normalcy we can focus our attention on questions involving the relationship between the media and politics, and the contribution of the media to the "quality" of Spanish 
democracy, without having to take into consideration the particular and extraordinary demands of the democratization and consolidation processes. By 1982, the Spanish party system had taken on a relatively stable configuration. Following the disappearance of the UCD (Gunther 1986, Linz and Montero 1986, and Gunther and Hopkin forthcoming) partisan politics at the national level came to be dominated by a very moderate, social-democratic PSOE, and a center-right to right Alianza Popular (renamed the Partido Popular in 1989). Finally, the structure of television broadcasting in Spain was transformed as the central government's former monopoly was brought to an end, first by the devolution to the new regional levels of government the right to establish their own public television networks, and then by allowing privatesector firms to establish their own nationwide broadcasting networks. This concluding section of the chapter will, therefore, be an exploration of "politics as usual" in Spain, and the role of an evolving media structure in Spanish democracy today.

\section{The Print Media}

Between the mid 1970s and 1998, the proportion of Spaniards over the age of 14 who read newspapers every day increased from $30-32$ to 36 percent. Nonetheless, Spain continues to lag far behind most other West European countries, whose average daily newspaper readership was 61 percent in $1994^{17}$. Two important reasons for this lag are Spain's late economic development (which began in earnest only in the 1960s) and the franquist regime's highly inadequate educational system. This is evident in the frequency of newspaper readership among our 1993 CNEP survey respondents, broken down into subcategories according to age and education. A relationship of moderate strength (Tau-B=.13, sig. @ .000) emerged when newspaper readers were broken down by age: 42 percent of those over age 50 (whose childhood socialization would have taken place prior to the economic takeoff of the 1960s) stated that they never read newspapers, as compared with only 30 percent of those under age 50. But this relationship is explained entirely by the fact that older Spaniards had vastly more limited educational opportunities than have younger Spaniards. When education is introduced as a control variable we find that, among the college educated and those completing secondary education, older Spaniards read newspapers somewhat more frequently than do those under age 50. The strength of the relationship between educational attainment and newspaper reading is substantial within both groups: the Tau-B among those over age 50 is .39, and among younger Spaniards it is .27. This would suggest that as the older generation of less-welleducated Spaniards are gradually replaced by cohorts whose educational achievements are comparable with those of other advanced, postindustrial societies, this distinguishing characteristic of Spanish political culture should fade.

Even when we take into consideration late industrialization and lagging educational opportunities, however, Spaniards read newspapers less frequently than other Europeans, presenting us with a puzzle. The same number of daily newspapers were being sold in Spain in 1980 as in 1931 (Alférez 1986, 225). But in 1931, Spain had 23 million inhabitants, between 30 and 40 percent of whom were illiterate, and over half of whom lacked formal schooling. Today, in contrast, Spain's population is nearly 40 million, illiteracy has virtually disappeared, and education is free and compulsory up to age 16. Clearly, something other than education explains these reading habits.

The boredom and monotony of the press during the decades of franquismo may simply have discouraged many Spaniards from regularly reading daily newspapers, and shifted their attention to the 
more lively and entertaining new medium, television. Over time, this may have become a behavioral norm with a life of its own. Another possible explanation has to do with a structural characteristic of the Spanish media, especially the daily press. In many respects the inability of newspapers to attract large audiences among the lower and lower middle strata of society is a product of the lack of a "popular press" whose language and news content might make them more accessible and attractive to persons with relatively little education. The major national newspapers in Spain are modeled after the small handful of "quality newspapers" found in Western democracies, and their relatively demanding vocabulary and detailed presentations of often complex issues make them inaccessible to many citizens. With the shift to the democratic press, some newspapers with the ability to appeal to the lower social strata (such as the daily Pueblo, run by the franquist corporatist trade union system) disappeared and were not replaced by others with a similar style ${ }^{18}$.

With regard to the overall structure of the newspaper market, Spain lies somewhere between Britain (dominated by newspapers with nationwide circulations) and the United States (where local papers predominate). The great majority of the 123 daily newspapers published in 1994 were local or provincial papers with geographically restricted circulation. A second group of newspapers are regional, some of which articulate regional-nationalist concerns, while others (in regions lacking nationalist parties or movements) merely focus their attention on regional issues ${ }^{19}$. However, newspapers with nationwide circulations (which account for over one third of all daily sales) have by far the greatest impact on national politics. Indeed, the country's political discourse largely dominated by a handful of newspapers published in Madrid. Outside of three areas with their own languages and cultures (Catalonia, Euskadi and Galicia), the regional and provincial press consists of minor, low-quality publications with extremely low circulation levels.

The most significant press development since the end of the transition period has been the birth of a new Madrid daily, El Mundo, whose sensationalist attacks on the PSOE and the González government have had a major impact on Spanish politics. This paper quickly attracted a following and assumed a prominent position in the newspaper market, previously dominated by the center-left $E l$ País and the rightwing $A B C$, with Diario 16 occupying a relatively small market niche ideologically sandwiched between the other two. By 1994, El Mundo's reported sales and readership roughly equaled those of $A B C$ and greatly exceeded those of Diario 16, although El País easily retained its position as the leading daily ${ }^{20}$.

The political stance of El Mundo is quite distinct from that of its two principal rivals, as indicated by data from our 1993 CNEP survey (corroborated by the findings of a much larger survey of 30,000 Spanish citizens) $)^{21}$. El País was perceived by 62 percent of its readers $(\mathrm{n}=95)$ as objective and not favoring any particular party, but the great majority of those who perceived bias (30 of 36) believed it favored the governing PSOE. $A B C$ has a much more clearly partisan profile, with 60 percent of its readers $(n=38)$ regarding the conservative daily as having a partisan bias, and half of its readers specifying that the Partido Popular was the favored party. These biases were confirmed by a systematic evaluation by a trained coder of newspaper articles dealing with the 1993 campaign $^{22}$. El Mundo appears at first glance not to have any partisan biases: only 16 percent of its regular readers $(n=42)$ said that it favored any party. Instead, its bias is manifested not in support for a particular party, but in its aggressively hostile stance towards Felipe González and his PSOE government. With its aggressive, muck-raking journalism (in which scandals involving government and party officials were headlined almost daily), it quickly filled a 
previously unoccupied niche in the relatively staid national newspaper market. In several instances, it uncovered important scandals involving unconscionably corrupt behavior by prominent government appointees (such as the Governor of the Bank of Spain and the commander of the Civil Guard) and involvement in illegal counterterrorist activities by the Minister of the Interior ${ }^{23}$. A useful journalistic function was thus performed by helping to purge corruption from a system that had been perhaps dominated by a single party for too long. But in other respects, the lack of a distinction between news reports and journalists' own opinions, the frequent lodging of unfounded allegations against the PSOE, and behavior which sometimes seriously violated the ethical standards of journalism revealed an excess of anti-Socialist zeal ${ }^{24}$. In the end, El Mundo succeeded in making corruption in public office the most salient issue throughout the period from 1993 through 1996, contributing to the PSOE's electoral defeat in that year. Unfortunately, its attacks and its indiscriminately shrill and rancorous tone have also helped to give Spanish politics a nastiness and an unsavory character that had been largely lacking during the transition -when the "politics of consensus" prominently featured civilized and restrained clashes between opposing party representatives, and a deeply entrenched sense of mutual respect, which substantially contributed to the consolidation of the new democracy (Gunther 1992a).

The three newspapers' biases are reflected in the ideological orientations and electoral preferences of their regular readers ${ }^{25}$. The mean self-placement on the left-right continuum (with 1 representing the far left and 10 the extreme right) of El País readers was a center-left 3.8, while that of $A B C$ 's followers was a right-of-center 6.1. Interestingly, El Mundo's readers placed themselves at 4.6 -a center-left position which is close to the mean placement of the PSOE on the left-right continuum by our CNEP respondents. Nevertheless, as can be seen in Table 4, El Mundo's readers gave far less electoral support to the PSOE (10 percent) than the Spanish electorate as a whole (38 percent). This represents a very significant departure from the least-ideological-distance principle which has been an accurate predictor of the vote in all previous Spanish elections (Gunther, Sani and Shabad 1986; and Linz and Montero 1986). While the small number of regular newspaper readers in our CNEP survey lessens the level of statistical reliability of these relationships, we should note that, once again, these findings are corroborated by other studies ${ }^{26}$ and by the consistency of findings across a large number of indicators. Overall, these findings suggest that reading a particular newspaper is closely associated with the holding of specific attitudes either directly or indirectly relevant to partisan preferences. As Table 5 clearly illustrates, the regular readers of these three papers were clearly differentiated from each other by their opinions concerning whether or not they believed that the government wastes "a large portion" of the taxpayers' money, that there is much corruption in public life, that the PSOE was more corrupt than other parties, and that Felipe González was "honest".

\section{Television}

The structure of television broadcasting has been substantially altered during this era of "democratic normalcy". A new statute for RTVE was incorporated within an Organic Law, passed in 1980 (see Maxwell 1995, 37), which established new "democratic" mechanisms for regulating state-owned broadcasting media. But despite the new Radio and Television Statute's commitment to impartiality, pluralism, the separation of news from editorial opinion, and the promotion of democratic values, creation of these new regulatory bodies did not end partisan tensions over the alleged pro-government bias of these media (Sinova 1983, 29-42). This is perhaps the logical outcome of one continued institutional 
linkage between the incumbent government and the country's largest television network: the director general of TVE remained a government appointee. Despite numerous other institutional changes, and the fact that partisan biases in coverage of politics on TVE are (as we shall see) quite modest, the continuation of this linkage (rather than replacing the government-appointed director with a strictly non-partisan governing body, like those which control the British Broadcasting Corporation or the American Public Broadcasting System) has led to charges by opposition parties of political favoritism by the public television network. No matter which party has been in control (the UCD from 1977 to 1982, the PSOE from 1982 to 1996, and the PP today), opposition parties have complained about bias in news coverage by the state-owned television network.

Initially, incremental reforms were implemented in an attempt to ensure greater objectivity and partisan balance in broadcasting by the state television network: oversight of the two state-run channels (TVE-1 and La 2) was institutionalized through the creation of a commission whose members are selected by a two-thirds majority vote in parliament. In the 1980s, more far-reaching structural changes were implemented, including the creation of regional broadcasting systems and several private-sector television networks. In the end, what had been a government monopoly, subjected to sometimes heavy-handed political control, was replaced by a highly pluralistic arrangement which, in the aggregate, provides for a high level of partisan balance in television coverage of political news.

Accompanying Spain's transition to democracy was an equally profound transformation which replaced the rigidly centralized and hydrocephalic franquist state with a highly decentralized political system (the Estado de las Autonomías -a regionally varying, quasi-federal system). This decentralization was a recognition of the cultural and linguistic pluralism of Spain's population ${ }^{27}$, and a response to demands by powerful Catalan and Basque nationalist parties for the reestablishment of extensive selfgovernment rights. Decentralization of the television system was an integral part of this larger transformation. In reaction against the franquist regime's linguistic and cultural intolerance, as well as concerns that the spread of Spanish-language television broadcasts posed a grave threat to the everyday use of the regional languages, Catalan and Basque political leaders placed the right to create their own regional television networks near the very top of their political reform agendas. The new Catalan and Basque regional governments, established in 1980, moved quickly to create their own broadcasting systems. The end result is that viewers in these regions have two additional regional stations to choose from -TV3 and Canal 33 in Catalonia, and ETB1 and ETB2 in Euskadi. Regular broadcasting in Catalan and Euskera has complemented the respective regional governments' policies promoting the everyday use of their regional languages ${ }^{28}$. This partial decentralization of television broadcasting has spread to other regions as well. The nationwide networks are complemented by Canal Nou in Valencia, TVG in Galicia, Canal Sur in Andalucía, and Telemadrid in Madrid.

More recently, media pluralism has been reinforced by enactment of a 1988 law permitting the establishment of private television channels to compete nationwide with the state-run stations ${ }^{29}$. In 1989, Antena 3 Televisión was the first private station to begin broadcasting. The Italian media magnate Silvio Berlusconi was the next to enter the field, initiating broadcasts by his Tele 5 in 1990. In 1994, Canal Plus España (modeled after its French parent) began entertainment broadcasting to those who pay annual subscription fees, in addition to unscrambled broadcasts of its news programs free of charge. Satellite television viewers (about 3 percent of the population) were presented with a still wider array of options ${ }^{30}$. 
By 1995, viewers in over 90 percent of the territory of Spain could receive all four of the nationwide freetelevision channels, in addition to the unscrambled portions of Canal Plus broadcasting. The overwhelming majority of the population (residing in the populous regions of Madrid, Catalonia, Andalucía, Valencia, Galicia and Euskadi) could also receive one or more of the regional channels.

Spaniards are heavy consumers of television broadcasts. Over 90 percent of the population watch television daily, and 67 percent of our 1993 CNEP respondents said that they followed the news on television every day (with another 12 percent watching television news broadcasts three or four times a week). The number of viewing hours has increased steadily since the introduction of private television in 1990: by 1994, the average Spaniard was watching about three and one half hours of television per day. In terms of audience shares, TVE- 1 and Antena 3 Televisión were the leaders, attracting about 25 percent of the viewing audience each. Tele 5 followed, with between 18 and 20 percent, La 2 regularly attracted about 10 percent of viewers, and Canal Plus another 2 percent. Regional television channels averaged about 16 percent of their respective geographical segments of the viewing public, ranging between the 25 percent of the Catalan audience that regularly watched TV3, to 5 percent of Basque viewers tuned into ETB1 (which broadcasts in Euskera, which is not an Indo-European language, and is spoken by something less than 30 percent of the population of Euskadi) ${ }^{31}$.

In terms of news broadcasts (whose typical length is 30 minutes), TVE-1 remains the preferred channel by a wide margin, with a share of 32 percent of the viewing audience for its lunch-time Telediario (3:00 P.M.), and a 27 percent share for its 9:00 P.M. news broadcast. Despite their comparatively limited technical and news-gathering resources, the private channels have quickly mounted a strong challenge to TVE-1. A recent survey found that, out of a total average daily exposure to television news of 38 minutes, TVE-1's share was 13 minutes, and the shares for Tele 5 and Antena 3 were 8 minutes and 7 minutes, respectively. Information consumption through regional channels amounted to an average of 8 minutes, while Canal Plus and La 2 (the second public-broadcasting channel) had just one minute each (Sofres 1997).

In contrast with the strongly biased and censored television news coverage under the Franquist regime, Spanish television in the mid 1990s was broadcasting the news in a reasonably objective manner. Our 1993 survey data, for example, reveal that very large majorities of the regular viewers of news broadcasts on each of the three major networks regarded those broadcasts as impartial. Seventy-five percent of the regular viewers of TVE-1 news broadcasts $(n=668)$ agreed that those programs did not favor any particular party, as did 76 percent of Antena 3 viewers $(n=254)$ and 86 percent of Tele 5 's viewers $(n=130)$. When asked which party was favored by the news broadcasts of each of these networks, 22 percent of the regular viewers of the state-run TVE said, not surprisingly, the governing PSOE. Balancing this perceived pro-government bias, 16 percent of Antena 3's regular viewers said that the news broadcasts they most frequently watched favored the Partido Popular. Eleven percent of the newsbroadcast viewers of the other major private channel, Tele 5, however, said that their preferred network favored the PSOE, while just 2 percent said that it was biased in favor of the opposition PP.

These survey findings are, by and large, consistent with other CNEP data based upon coding of media broadcasts by trained observers. During the course of the 1993 election campaign (including both the official campaign, which lasted from May 21 through June 6, and six days of the preceding "pre- 
campaign"), a total of 335 television news broadcasts were taped and content analyzed. Of the 5,536 news segments broadcast, 1,921 dealt with politics, and were coded using a detailed system (which generated over one hundred different variables for each of those 1,921 news items) ${ }^{32}$. The several different indicators of bias built into the coding scheme clearly reveal that partisan favoritism exists, but also that these biases are quite moderate and uneven across various indicators, and that, in 1993, the preferences of one network were balanced by the contrary orientations of another. Thus, in the aggregate, there was a high level of pluralism in Spanish television coverage of this election campaign, providing Spaniards with a wide and relatively balanced variety of viewpoints.

One indicator involves the ability of a political actor to initiate a news article and, thereby, influence the agenda of the election campaign. In this respect, there was almost no difference among television networks: they all allowed the governing PSOE to initiate a larger number of news items than the major opposition party, the PP, although the difference was not very substantial. The PSOE initiated 15 percent of all news items dealing with political matters, as compared with the 9 percent for the PP. When one realizes, however, that an additional 7 percent were initiated by Izquierda Unida, and another 15 percent by other parties, the ability of the governing party to dominate the content of television news broadcasts appears to be rather marginal. The visibility of political figures in this coverage reveals a wider margin in favor of the PSOE, and again does not greatly vary from one network to another. In the course of 335 news broadcasts, leaders of the six major parties were mentioned by name a total of 1,117 times, of which 47 percent were references to PSOE representatives, as compared with only 17 percent for the PP, 13 percent for Izquierda Unida, 8 percent for the CDS, and 5 percent, each, for the Catalan CiU and the Basque PNV.

Similarly, the amount of time that political leaders spoke on television gave a significant advantage to the governing party over its closest rival, the PP, particularly during the "pre-campaign" period $^{33}$. This was true with regard to all channels, both public and private. This advantage is offset, however, by the multi-party character of Spanish democracy. When the time devoted to coverage of all opposition party spokespersons is summed, messages by PSOE leaders are roughly balanced by others criticizing its performance in office during the "pre-campaign". During the official campaign, the amount of time devoted to opposition-party messages significantly exceeds those of the government on all television channels $^{34}$.

These indicators, however, do not tell us whether the news coverage was favorable to the principal object of the news segment or was critical. Three indicators of evaluative biases of television reporters and anchors give a much clearer picture of the extent of network partisan favoritism. One item asked coders to count the number of evaluative statements made by the reporter in each news segment (up to five such statements per news item), and to indicate whether these statements were positive or negative towards the relevant parties. Over the course of 1,921 news segments, reporters made a total of 97 statements favorable to the PSOE, and 151 casting it in a negative light. There were also 51 positive references to the PP, and 127 unfavorable statements. The most striking conclusion to emerge from these data is that Spanish television reporters and anchors generally shy away from making evaluative statements about parties: the combined total of all positive and negative statements concerning the two largest parties amounted to just 426 out of the 1,921 news segments covered -that is, an average of one evaluative statement out of every five political news items. As Díez Nicolás and Semetko (analyzing these 
same data) have written: "The immense majority of statements...were descriptive, neutral, without evaluative judgments concerning the actors in the news" $(1995,286)$.

When evaluative statements are broken down by network, and steps taken to estimate the net balance of these assessments by each news organization, several points emerge clearly. The first is that, like television journalists in the United States, Spanish reporters and anchors of all networks tend to make more critical than favorable comments about politicians and parties in general (see Table 6). With the exception of Tele 5, the results presented here are consistent with those derived from the perceptions of our survey respondents. The governing Socialists did benefit in the 1993 election from more positive statements about the PSOE and more negative evaluations of the PP on TVE-1. This was largely offset by the net balance of evaluative comments about the PP broadcast by all the other channels surveyed, including (by a tiny margin) TeleMadrid, which was operated by the PSOE government of the region of Madrid. The partisanship implicit in these figures, however, is most restrained. No network was seriously biased in favor of one or the other major party.

A similar mixed picture emerges when we examine a second variable: expressions of "disdain" towards political parties. Coders were asked to identify reporters' comments that reflected cynicism towards a particular party. In this instance, TVE-1 emerges as the most balanced of the network news broadcasts: in only 3 percent of the 525 news items covered by TVE- 1 was disdain expressed towards the $\mathrm{PP}$, as compared with 2 percent towards the PSOE, giving the PSOE a net advantage of 1 percent. The most partisan stand was taken by reporters and anchors of Antena 3, who made a net of 4 percent more snide remarks about the PSOE than about the PP. The other channels ranged between these extremes: expressions of disdain by Tele 5 journalists were more negative towards the PSOE by a net of 1 percent, while Canal+ and TeleMadrid reporters made more cynical remarks about the PP, by net margins of 1 and 3 percent. In general, such expressions of disdain were very infrequent, and more commonly involved cynical remarks referring to "all parties" than to any one of them in particular.

An equally mixed picture emerges from an examination of data derived from a third indicator, in which coders were asked to use a scale from one to seven indicating how favorable or negative reporters' remarks were towards each party's national leader. When the mean of all such ratings were calculated for each network, and the negative scores were subtracted from the mean of the positive evaluations, Felipe González could be seen as favored by TVE-1 (a mean of 0.5 points), TeleMadrid (1.5), and Antena 3 (0.4). PP leader José María Aznar benefitted from a more favorable coverage on Canal+ (0.5) and Tele $5(0.2)$ broadcasts.

Overall, the Spanish television media were quite pluralistic and inconsistent in their patterns of bias. The slight pro-government bias of the state-operated TVE-1 was effectively canceled out by the antigovernment sentiments articulated more frequently on the other networks ${ }^{35}$. Clearly, there was no "pack journalism" apparent, in which a climate of opinion among journalists decisively favored one party or the other (unlike in the 1992 American presidential election, when a significant anti-Bush sentiment was apparent in both newspaper and television coverage of the campaign ${ }^{36}$, or in the 1994 congressional election, following two years of hostile media criticism of Democratic incumbents). Just as important, the biases that were exhibited by the various television networks were quite restrained. Overwhelming majorities of our survey respondents believed that their preferred news broadcasts were impartial, findings 
that are entirely consistent with the extensive content analysis of news broadcasts during the 1993 campaign itself.

The relative lack of bias exhibited by Spanish television journalists would appear to be, at least in part, the product of a particular broadcast-journalism style that limits opportunities for the infusion of personal bias and editorial comment by reporters. In sharp contrast with American television, where "sound bites" allowing politicians to state their own positions have been reduced to an average of 9 seconds, and where the great bulk of each news broadcast is devoted to the reporter's own "interpretation" of what was said or meant by a politician or news event, Spanish television is largely restricted to a "straight news" format. Spanish reporters rarely pontificate or reinterpret statements or news events. The actual protagonists in the news are the political elites themselves, rather than reporters, anchors or commentators. Spanish politicians were allowed to speak, uninterrupted, for an average of 24 seconds during the course of the campaign ( $n=2,067$ sound-bites timed by our coders). Indeed, only 13 percent of Spanish politicians who appeared on television were allotted the American average sound-bite of 9 seconds or less. Moreover, a much larger portion of these news broadcasts was devoted to the actual policy proposals of the respective parties than is typical of American election coverage. Fully 32 percent of the 1,921 political-news items studied by our coders dealt with public policy issues ${ }^{37}$. Finally, contrary to the American model, very little attention was paid to the so-called "horse race" aspects of the campaign, in which polling data concerning who is ahead at each stage of the campaign serves as the principal subject of the news story. Only 2 percent of the 1,921 news items broadcast during the 1993 campaign focused on which party was in the lead at that point in the race.

The Electoral Impact of Media Bias. Despite the fact that most Spaniards regarded their favorite news broadcasts as unbiased, our 1993 survey data suggest significant media effects on their voting preferences. At first glance, these effects would appear to be substantial: among regular TVE-1 news broadcast viewers, 58 percent $(n=295)$ voted for the PSOE in the 1993 election, and only 30 percent $(n=153)$ voted for the Partido Popular, among viewers of the other channel seen by viewers as favoring the governing party, Tele 5, 57 percent $(n=47)$ voted for the Socialist party, and 32 percent $(n=26)$ supported the PP; in sharp contrast, among Antena 3 viewers, only 35 percent $(n=61)$ cast ballots for the PSOE, while 55 percent (n=97) supported the Partido Popular. On closer inspection, however, we must conclude that these media effects are more modest, since there is a tendency of some viewers to select television news broadcasts that largely conform to their own partisan or ideological biases ${ }^{38}$. When left-right selfplacement was introduced as a control variable, this relationship between viewing habits and electoral support decreased considerably. Indeed, among those with marked ideological preference for the left (positions 1, 2, 3 or 4 on the ten-point left-right continuum) or the right (7, 8, 9 or 10), there was no significant relationship at all: irrespective of which channel one watched, persons with such clear-cut ideological stands were not about to abandon the party to which they were closest on the left-right scale. Among those at the center of the political spectrum, however, viewing habits appear to have made a difference electorally. If we examine only those who placed themselves at position 5, the center of the political spectrum, we find that among TVE-1 viewers $(n=69) 75$ percent voted for the PSOE in the 1993 election, while only 22 percent cast ballots for the PP. In contrast, among regular Antena 3 viewers in that same left-right category $(n=22), 50$ percent supported the PP and 45 percent the PSOE (findings significant at the .05 level). 
These data suggest that media effects are most likely to be interactive with other attributes of voters. One of these attributes is the initial ideological stance of the individual: among those voters with firm political ideas and preferences, media effects will most likely be negligible, but among those near the center of the political spectrum, whose political attitudes may be mixed, weakly held or non-existent, even subtle biases in news coverage may have a measurable impact on electoral preferences. What is particularly significant about this finding is that in Spain, as in many other political systems, the ability to attract large numbers of votes from the moderate center of the political spectrum is the key to electoral success. Thus, those individuals who are the key swing votes in close elections are precisely those who may be most susceptible to media influences of the kind under examination here.

Consistent with this "swing voter" hypothesis, there is some evidence that the erosion of electoral support for the PSOE since the previous election may have been somewhat enhanced by the way television channels presented news events during the four intervening years. Among those who had voted for the PSOE in 1989, and who regularly followed the news on TVE-1 ( $n=305)$ during the 1993 campaign, over 78 percent voted for the Socialist party again in that contest. But among those 1989 Socialist voters $(n=78)$ who watched the anti-PSOE Antena 3 (which did not exist in 1989), only 57 percent did so again in 1993, with 30 percent shifting to another party and another 13 percent not voting. Since we can conclude that some prior partisan predisposition did not lead these respondents to opt for one television network over the other (since all of this subsample had voted for the socialists four years earlier), we can lay to rest doubts about the direction of causality underpinning these statistical relationships.

Overall, the effects of media bias on electoral behavior in Spain are of only moderate strength, and are interactive with other determinants of the vote, such as initial ideological or partisan predisposition. It is important to note, however, that the moderate strength of these relationships is consistent with the relatively restrained nature of television network bias in Spain. One is tempted to speculate that if TVE-1 had not been subject to democratic controls by the inter-party oversight body, and that if the official campaign period did not impose additional restrictions designed to enhance fairness, the government's broadcasting network might have more overtly and effectively supported its reelection campaign. And it is undeniably true that termination of the state's monopoly over television broadcasting has brought about much higher levels of pluralism in the political-information market. Voting behavior in democratic systems where such safeguards have broken down (such as briefly occurred in Italy, where the Berlusconi government completely dominated both public and private television networks) is much more likely to be substantially affected by media biases ${ }^{39}$.

The Main Event: González vs. Aznar. Media effects should be most clearly observable in analyses of panel data collected prior to and following an election campaign. It is during election campaigns when individuals are asked to make unequivocal choices among various partisan alternatives on the basis of a flood of information presented to them through the media. Our 1993 survey was based upon a panel design that makes such analysis possible. We were particularly fortunate in focusing our attention on that campaign, since it is the first in over a decade to produce an outcome different from preelection expectations. And it was the first Spanish election that featured the quintessential televisioncampaign event: a face-to-face debate between the leaders of the two major parties. But before presenting an analysis of panel data intended to estimate the impact of this debate on the outcome of the 1993 
Spanish election, a brief description of the basic structure of television coverage of election campaigns is in order.

Perhaps the most important difference between television coverage of electoral competition in Spain and the United States is the complete ban on advertising (on both public and private networks) and the allocation on both public television and radio public networks of free air time for all political parties ${ }^{40}$. Unlike in American election campaigns -where candidates use television commercials to mold images and attract "buyers" in the same manner as toothpaste and under-arm deodorant are marketed, and where facile slogans are all than can fit into 15- or 30-second slots- Spanish parties and candidates appearing on television are placed in a setting where they actually have to say something about where they stand on issues. All parties fielding candidates in at least 75 percent of the provinces receive a free broadcasting slot of ten minutes, and larger parties (in accord with their shares of the vote in the previous elections) receive more free air time, ranging up to 40 minutes each for the two largest parties. (Purely regional parties are also given 15 minutes of free air time, if they received over 20 percent of the vote within their respective regions). Fairness in the allocation of these time slots is guaranteed by strict oversight by the Radio and Television Committee of the Junta Electoral Central ${ }^{41}$. This format does not by any means guarantee the veracity of the claims made by parties and candidates, neither does it force party representatives to stick to the "high road" of discussion of policy alternatives, but it does establish a context within which mere slogan-mongering would look foolish. Similarly, although the public networks' allocation of slots to political parties does systematically favor the larger parties over the smaller parties (with prime-time reserved for those parties with the largest percentages of the vote in the previous election), this source of bias pales in comparison with those arising out of the necessity in American campaigns to purchase expensive television commercials in order to be elected, thereby giving an enormous advantage to wealthy candidates or those with special access to well-heeled and well-organized special interests.

A second noteworthy feature of regulations governing Spanish election campaigns is that the Junta Electoral Central strictly oversees and regulates the behavior of both the broadcast media and parties during election campaigns. Parties are prevented from engaging in campaign behavior prior to the start of the official election campaign 15 days prior to the vote, although controversy always arises concerning de facto campaigning (i.e., in which parties portray themselves in the most favorable light, but without actually asking citizens for their votes) during the so-called pre-campaign. There is little ambiguity, however, concerning oversight of the broadcast media during the official campaign period: the Junta Electoral Central exercises the strictest vigilance of the public media ("stopwatching" coverage of the various parties on news broadcasts, for example) in an effort to guarantee neutrality and objectivity.

The 1993 election was (to date) unique in that it featured a face-to-face debate between candidates of the two leading parties. The creation of private networks (which are not constrained by the same equal-time provisions as the state networks) allowed for the holding of two such debates between Felipe González and José María Aznar during the 1993 campaign, as well as a series of debates among second-ranking party representatives. While the debates among minor party luminaries had low ratings (fewer than 7 percent of our 1993-survey respondents reported that they watched one of these secondary debates), the clashes between the leaders of the two largest parties drew enormous audiences: 70 percent of our respondents stated that they saw at least one of the two debates, and 49 percent said they watched both. Among other things, the much greater audiences for the Aznar/González debates are indicative of a 
"presidentialization" of electoral politics in Spain ${ }^{42}$.

These debates were without precedent, and emerged as the main events of the 1993 campaign (Wert 1994). Unlike American presidential debates (which are a succession of short speeches by candidates rather than true clashes of opinion), these involved a great deal of give and take. In accord with the opinions of expert observers, our survey respondents thought that Aznar won the first debate, by a margin of 31 to 15 percent over prime minister González. Their opinions were also consistent with the view that González more decisively won the second debate, with 38 percent believing that he emerged victorious from that encounter, as compared with only 7 percent who thought that Aznar won.

Most observers had expected that the PSOE would be swept from power in 1993. A decade after its triumphant 1982 victory (in which the PSOE attracted 48 percent of the popular votes and 58 percent of the seats in the Congress), the Socialist government of Felipe González was showing signs of having worn out its welcome. The Spanish economy was slumping badly, after having expanded at the fastest rate of growth in the EC from the mid to the late 1980s. The election was held in the midst of the worst economic crisis in three decades, with gross domestic product falling by one percent, unemployment reaching over 22 percent of the labor force, and the Peseta being devalued by 22 percent (the third devaluation in one year). The climate of public opinion was made even more negative by a series of scandals involving financial practices of the governing party and outright corruption by some of its more distinguished members. In combination with the usual erosion of public support that follows on the heels of over a decade in office, these circumstances made the PSOE's prospects for continuing in government quite dim. Indeed, the final published poll revealed that just one week prior to the official start of the two-week campaign, the PP had nudged ahead of the PSOE in terms of stated voting intentions, leading the government party by a margin of 35.5 to 33.9 percent $^{43}$. There were widespread expectations that the election would culminate in the formation of a new government under the PP's youthful leader, José María Aznar (Sinova 1993). Instead, the PSOE was returned to power and attracted over a million more votes than in 1989, although, given higher turnout (by more than 3.5 million more voters), this represented a modest decline of 1.5 percent in its share of the popular vote. Controlling 45 percent of the seats in the Congress of Deputies (as compared with 40 percent for the PP), the PSOE formed a single-party minority government supported de facto by the Catalan Convergència i Unió. The PP did make spectacular gains, increasing in popular votes by three million and in share of the total vote by 8.5 percent (from 26.3 to 34.8 percent), but in spite of all pre-election forecasts, the PSOE was able to form a homogeneous and stable government for the fourth consecutive time. Thus, a prima facie case can be made that this was one election when the campaign itself made a significant difference.

Some preliminary studies have argued that this unexpected electoral outcome was the product of changes in partisan preference by many voters during the campaign itself (e.g., López Pintor, et al 1994, 611-612), while others have asserted that this was the result of the mobilization during the campaign of habitual non-voters, attraction to the PSOE of a disproportionate number of undecided voters, and retention of former PSOE voters who were contemplating a shift to the IU or abstention (Arango and Díez 1993; Wert, López Pintor and Toharia 1993; and Díez Nicolás and Semetko 1995). Most commonly cited as a decisive factor in the Socialist party's victory was the second televised debate between González and Aznar, in which the prime minister succeeded in reversing the momentum of the campaign (Wert 1994). 
If González's victory in the second televised debate was as decisive in determining the outcome of the election as these observers have claimed, then we should expect to find that a disproportionate number of those who regarded González as the winner should have shifted their support to the PSOE in the aftermath of that television event. Our panel data reveal that 23 percent of the 416 respondents who were undecided on the pre-election wave of our panel study eventually voted for the PSOE, while only 14 percent opted for the PP; 41 percent apparently remained undecided and reported in post-election interviews that they did not vote. Given that 29 percent of those interviewed in the pre-election round fell within this undecided category, the magnitude of this electoral shift during the course of the campaign is significant. It represented a net gain for the PSOE (over pre-election statements of voting intention) of 4 percent of all votes eventually cast -a figure which is remarkably close to the difference between the 33.9 percent that the final pre-election CIS poll predicted for the PSOE and the 38.8 percent it actually received on election day.

Our panel data indicate that the second televised debate between the two candidates was decisive in bringing about this shift. Among those who were undecided at the time of the pre-election panel survey who eventually voted for either the PSOE or PP $(n=104), 68$ percent thought that Gonzalez was the clear winner, while only 12 percent regarded Aznar as the victor. Among the initially undecided voters who thought that González had won, 82 percent eventually voted for the PSOE, and only 18 percent supported the PP. Conversely, among the much smaller number who thought Aznar had won the debate, all twelve respondents cast ballots for the PP. These data are not only statistically significant (at the .001 level), but, given the crucial role of these swing voters in determining the outcome of the election, they represent clear evidence that television coverage of a key campaign event can have considerable political significance as well. This kind of "media effect" is different from that resulting from partisan bias on the part of journalists, insofar as the politicians themselves are the only protagonists in the drama, but it is one in which an altered outcome would probably not have materialized if news about this event had been channeled to voters through any medium other than television ${ }^{44}$.

\section{Radio}

Radio listening has undergone a remarkable comeback in Spain over the past two decades. In 1973, only 35 percent of Spaniards over the age of 14 reported that they listened to radio daily; by 1994, that figure had climbed to 55 percent. Most of this increase occurred during the transition, but there has been a steady expansion of the radio audience since then as well. Of particular significance is the proliferation of highly politicized talk-shows, in which reporters and journalists engage in often lively arguments about political matters (Santos 1995, 136-142). SER, COPE and Onda Cero each broadcast three such programs during the day, which attract an estimated daily audience of three million. The tone of these debates is often quite contentious, and goes well beyond the bounds of what would be tolerated in the print media ${ }^{45}$. Given these and other types of programs, radio has become a much more intensely politicized medium than television. The regular audience following political news on the radio, however, is much smaller than that of television. In our 1993 post-election survey, 82 percent of respondents said that they had followed the campaign by watching television news, but only 33 percent claimed to have listened to radio news broadcasts about the campaign.

The largest radio networks are the SER chain (owned by the PRISA group, which also publishes 
El País), with 34 percent of the market, the COPE network (owned by the Catholic Church and some private investors), with 24 percent, Radio 1 (a state-run conventional radio station), with 17 percent, Onda Cero Radio (owned by ONCE, the parastate organization which provides various forms of support for the blind), with 15 percent, and the state-run, all-news Radio 5, with 7 percent of the radio audience. Those specific programs with the largest followings are the morning broadcasts of SER (with nearly 2 million listeners) and COPE (with over 1.5 million).

When asked whether their preferred radio station favored a political party, the responses given by regular radio listeners perfectly parallel those of the television viewers described above: the great majority (ranging from 68 percent of COPE listeners to 87 percent of the Radio Nacional audience) said that their respective networks were impartial in covering the news and did not favor a political party. Nevertheless, among regular listeners who acknowledged bias by their favorite stations, unequivocally clear pictures of partisan favoritism emerged: Antena 3, and, especially, COPE and Onda Cero were perceived as favoring the PP, while SER and Radio Nacional were regarded as supporting the PSOE ${ }^{46}$. Given the relatively small numbers of regular radio listeners in our sample, the necessity of introducing control variables into the analysis, and the remarkably comparable partisan compositions of the regular audiences of COPE, Onda Cero and Antena 3, on the one hand, and those of SER and RNE, on the other, the following analysis will be based upon a dichotomization of regular radio listeners into those two camps.

As in the case of television, an initial glance at the relationship between radio listenership and the choice between the PP and the PSOE in the 1993 election would give a misleading impression of an extraordinarily strong relationship. When the sample is further dichotomized to include only those who voted for the PSOE or the PP in 1993 we find that two thirds of the regular listeners of Antena 3, COPE and Onda Cero (hereafter, "the conservative channels") voted for the PP in that election, while three quarters of RNE/SER listeners supported the PSOE, producing a Tau-B of .42 between the two variables (significant at the .0001 level) $)^{47}$. To a much greater extent than among television viewers, however, it is clear that radio listeners choose stations compatible with their ideological preferences, with right-wing and/or religious Spaniards opting for the conservative channels, and those to the left of center listening to RNE or SER stations $^{48}$. Thus, it is necessary to introduce ideological self-designation as a control variable. To a greater extent than among television viewers, this leads to the complete disappearance of any significant relationship among those on the left (who located themselves at positions 1, 2, 3 or 4 on the ten-point scale) and right (7, 8, 9 and 10). For these individuals, the political biases of their respective radio stations were insufficient to overcome their standing attitudinal convictions and support a party on the other side of the left-right cleavage. As among television viewers, however, those at the center of the political spectrum appear to have been quite responsive to these media biases. Among those who placed themselves at position 5 on the left-right continuum, 86 percent of those who regularly listened to RNE/SER ( $n=22$ ) news voted for the PSOE, as compared with only 50 percent of those who listened to the conservative stations ( $\mathrm{n}=18$, Tau- $\mathrm{B}=.39$, sig. @ .01). Among those who placed themselves at position 6,91 percent of those who followed the news on the conservative stations $(n=21)$ voted for the PP, as compared with only 46 percent among those who listened to RNE/SER ( $n=11$, Tau-B=.49, sig. @ .005). If we were to combine categories 5 and 6 into one centrist cell (which is standard practice, but in this case conceals a significant difference between the two scale positions), we would see that 76 percent of those falling into this ideological category who regularly listened to RNE/SER ( $n=33$ ) voted for the PSOE, while 72 percent of 
COPE/Onda Cero/Antena 3 listeners (n=39) supported the PP in 1993 (Tau-B=.47, sig. @ .0001).

Thus, as in the case of television viewers, it would appear that media effects are most notable among those centrists whose attitudes are more malleable than those who clearly locate themselves on the left or on the right. Also consistent with our findings concerning television viewership, those most susceptible to the influences of media biases may also be the "swing voters" who can determine the outcome of election campaigns. Among those who had voted for the PSOE in 1989 and who were regular radio listeners ( $n=135), 94$ percent of those who followed the news on RNE/SER remained loyal to the Socialist party four years later, while among those who regularly listened to one of the conservative stations 23 percent defected to the PP in 1993 (Tau-B=.24, sig. @ .005).

\section{THE MEDIA AND POLITICS IN SPAIN TODAY: AN ASSESSMENT}

An assessment of the impact of the media on Spanish politics today must begin with an awareness that the media system has been dominated by television since the 1970s. The preponderance of television as the principal channel of political communication in contemporary Spain is consistently revealed in surveys of the Spanish electorate. The CNEP survey of the 1993 election, for example, included three different measures of the frequency with which respondents followed political news through each communications medium. One was a question in the pre-election interview asking "how frequently you follow political news through..." newspapers, magazines, television and radio. The second was a postelection survey question asking how often the respondent had followed political news during the recent election campaign. The third item was more specific, asking each respondent which newspaper/magazine/television news broadcast/radio network he/she had read/etc. about politics during the previous campaign. As can be seen in Table 7, the resulting data are remarkably consistent. Except for some exaggeration of the frequency with which politics was followed through magazines and radio reported in the more general pre-election question, these data indicate that, by wide margins, Spaniards follow news about politics through television, while extraordinarily few respondents read about politics through news magazines. These data make it clear why television was regarded as the most influential medium by 82 percent of our respondents, as compared with 7 percent who selected radio, 5 percent who so regarded newspapers, and less than one percent who placed news magazines in this category. While levels of television viewership in other industrialized countries are comparable to those found in Spain, the relative political importance of television is greater than in most established democracies due to the weakness of Spain's alternative communications media.

Other data give some indication as to why television has been selected as the preferred medium of mass communication by most Spaniards. Table 8 presents responses to three questions asking respondents to identify the medium which is most credible, the one which is most informative, and the one which is most easy to understand. As can be seen, television is selected by pluralities or majorities of respondents as the answer to each of these questions.

The emergence of television as the preferred medium in response to each of these questions is worthy of some additional comment. First, we should recall that television was also regarded as the most credible medium under the Franco regime, even though it was the most closely controlled and censored 
medium under that authoritarian system. It would appear that many viewers place a certain blind faith in television that may, in some instances, be unwarranted. Second, our respondents' reports that television is the most "informative" medium does not hold up well in light of other data supplied by these same individuals. A political knowledge score was constructed out of responses to four of our CNEP questionnaire items, in which respondents were asked to identify four prominent public figures ${ }^{49}$. A clear positive association was found between the frequency of newspaper reading and the respondents' scores on this political information test even after education was controlled. The Pearson's $r$ correlations for each educational sub-group (primary education or less, complete secondary education, and higher-education) ranged between .30 (among the least educated) to .37 (among high school-and college-educated respondents), and all of these measures of association were significant at the .0001 level. A relationship of moderate strength emerges between the frequency with which political news is followed on the radio and the political information score: Correlations ranged from .16 to .28 among the three educational sub-groups (with the significance levels for the two less educated categories at .0001 , while for the smaller college educated group these results were significant at the .05 level). In short, the more one follows political news on the radio or, especially, in the newspapers, the greater one's political knowledge level. The frequency with which political news was followed through television broadcasts, however, was more weakly associated with respondents' levels of political knowledge, despite the fact that Spanish television news has a much denser public-policy content than American television news: correlations within the two less educated sub groups were both .16 and .17. Among those with college education, however, there was no statistically significant relationship between the frequency of television news viewing and political knowledge. Thus, the less well educated acquire some factual information about politics from television viewing (but much less than from reading newspapers or following the political news on the radio), but the incremental political knowledge gained by better educated citizens is negligible. In accord with a commonly hypothesized but rarely tested notion (e.g., see Ranney 1983), television does not appear to be a good medium for the conveying of factual information to viewers, and it certainly pales in comparison with the extent to which regular newspaper readers exhibit a detailed knowledge of political events.

These data suggest that television is the preferred medium among most Spaniards because it is "the easiest to understand," and therefore is the medium which disseminates political information at the lowest cost (in terms of time and effort) to the viewer ${ }^{50}$. Verbal and often graphic presentations of news about politics appear more readily accessible to the less-well-educated majority of the mass public than does the often dense and confusing presentation of political information through the print media. Given that the major national newspapers should all be classified as "high quality" media (using the distinction first developed in Britain), those with relatively low levels of educational attainment have no recourse to a "popular" or tabloid press, and thus rely predominantly on television for information about politics. This does not necessarily have negative implications for the quality of Spanish democracy: in contrast with the unconscionable bias and sensationalism of the British tabloid press, both public and private television in Spain do a reasonably good job of presenting a considerable amount of political information to their viewers in a relatively balanced (or at least subtly, not blatantly, biased) way. On a world scale they are closer to the television news broadcasts of the BBC than to those of the major American television networks (Miller 1991).

This empirical study of the 1993 parliamentary election has uncovered some evidence of "media effects" on Spanish politics. The most significant example of the influence of a news medium was that of 
the second televised debate between the country's leading political rivals. In this television era, it would appear that the personal campaign performances of a few prominent individuals can have a significant impact on electoral outcomes. In this sense, it is clear that the personalization or "presidentialization" of politics, even in parliamentary systems, is becoming an important feature of campaign politics in the modern era (also see Sartori 1998).

We have seen that the relatively modest political biases of news coverage by newspapers, radio and television have had some impact on Spanish politics, but their capacity to affect voting decisions appears to be largely restricted to those near the center of the political spectrum -including both "true centrists", with moderate, non-ideological orientations towards politics, and "false centrists", who locate themselves near the center largely by default, lacking well-defined attitudes towards most political issues ${ }^{51}$. Another factor which makes the aggregate political impact of the media relatively modest is that the predominant behavioral norm among television journalists is conducive to "straight" news reporting and the avoidance of editorializing, at least compared with their counterparts in the United States. In addition, overall, there is a great deal of pluralism among information sources in the Spanish media market -with El País, TVE-1, Tele 5, the RNE stations and the SER radio network perceived as favoring the PSOE in 1993, and the conservative opposition benefitting from the partisan biases of Antena 3 television, the COPE and Onda Cero radio stations, and such newspapers as $A B C$ and $E l M u n d o$. In this respect, the quality of democracy in Spain has been reasonably well served to date.

But what of subsequent elections and the future? A study of the media in the 1996 Spanish parliamentary election revealed the same patterns of relatively balanced and restrained coverage of the campaign by television, but it also provided some crucial insights into the factors underpinning these patterns. Basing their analysis largely on newsroom observation and interviews with the editors of the two major networks (TVE-1 and Antena 3) during the official campaign, Semetko and Canel (1997) concluded that the public-service broadcasting ethic which guided the behavior of the TVE-1 news editors led to "a constant determination to achieve an appropriate balance in the electoral block of coverage.... Election news on TVE-1 in the official campaign was largely descriptive, with little or no evaluative comments from reporters.... Election news was 'straightjacketed' into the formula called the electoral block, which was rigidly 'balanced,'... to such an extent that on a day when there were no rallies to report, news professionals actually called the parties to ask them what they wanted covered that day!" (Semetko and Canel 1997, 475). Only election coverage by television in Japan appears to have been guided by such a concern with partisan balance (see the chapter by Krauss in this volume). And in contrast with the confrontational and disdainful stance often adopted by American reporters when interviewing candidates, the TVE-1 bureau chief who interviewed all the party leaders described his aim as "to be 'respectful' and 'let them speak' to viewers about what they were interested in" (Semetko and Canel 1997, 475).

But the Semetko and Canel study also "showed that there were profound differences in attitude and approach taken by the two main competing news organizations.... News professionals at Antena 3 would have found it anathema to call the parties and ask them for their most important story of the day. Instead, reporters and producers there made a special effort to initiate news via analysis and interpretation.... News on Antena 3 was also ironic and critical, occasionally disdaining and frequently entertaining. There was some sacrifice of substance for style. Instead of focusing on the substantive issues addressed in a speech at a rally, for example, Antena 3 reported on the style or tactics of the leader, 
or offered a humorous piece on how the leaders move -Felipe's feet or José María's hands.... The aims of the young Antena 3 were everything that TVE-1 was not" $(1997,476)$.

This presents us with decidedly different scenarios for the future. Will the entertainment orientation, gratuitous and disdainful editorializing, and low information content that has progressively crowded hard news coverage out of nightly news broadcasts on NBC and ABC in the United States increasingly characterize the newsroom orientation at Antena 3, or perhaps spread to other television networks in Spain? Will the "straightjacket" which TVE-1 journalists had strapped on be cut loose -allowing the incumbent government to manipulate campaign coverage more blatantly than in the past? It is already clear that the change of government which occurred as a result of the 1996 election (bringing to power a PP minority government) has shifted the overall partisan balance in the television sector: the new government immediately replaced the director general of TVE-1, who, in turn, replaced the network's editors and bureau chiefs. Without doubt, this channel's modest pro-PSOE biases in the past have been reversed, although no content analysis of TVE broadcasts have as yet been undertaken in an attempt to quantify this shift. Will other changes take place in the future, possibly shifting TVE-1 from the core tenets of public-sector broadcasting? The question of how to combine some editorial freedom for journalists with the need to provide balanced and unbiased information on issues poses obvious questions regarding governance and regulation, particularly concerning the public sector of television broadcasting. An independent structure of administration, based more upon professional expertise than upon political patronage and government intervention would probably provide better opportunities for providing the political information necessary for well-informed public opinion. These and other matters pertaining to the long-term evolution of the relationship between politics and the media in Spain remain open questions. 
Table 1

Percentages of Survey Respondents Who Have Television Sets and Watch Television

\begin{tabular}{lccccc}
\hline & 1966 & 1967 & 1969 & 1973 & 1975 \\
\hline & & & & & \\
Have Television Sets & 33 & 36 & 68 & -- & 81 \\
Usually Watch Television* & 54 & 54 & 81 & 91 & -- \\
\hline
\end{tabular}

* This figure is greater than the percentage who own television sets because of access to television in public bars, tele-clubs, the houses of friends and relatives, etc.

Sources: For 1966, IOP (1967, 160-3); 1967 and 1973, IOP (1975b, 265); 1969, IOP (1969, 338-342); and 1975, Wert $(1976,124)$

Table 2

Medium Through Which Spaniards Received Information Concerning Selected News Events (\%)

\begin{tabular}{lccccc}
\hline Event & Newspapers & Radio & Television $\begin{array}{c}\text { Other } \\
\text { People }\end{array}$ & $\begin{array}{l}\text { DK, } \\
\text { NA }\end{array}$ \\
\hline British Elections (1964) & 40 & 25 & 33 & 2 & -- \\
US Elections (1964) & 30 & 32 & 34 & 4 & -- \\
Italian Elections (1965) & 52 & 15 & 30 & 3 & -- \\
Vatican Concilium (1965) & 38 & 23 & 30 & 2 & -- \\
US Space Flight (1965) & 29 & 19 & 49 & 3 & -- \\
Soviet Space Flight (1965) & 36 & 23 & 31 & 10 & -- \\
Spanish Referendum (1966) & 13 & 19 & 34 & 7 & -- \\
\hline
\end{tabular}

Source: González Seara (1967a, 40)

Table 3

Support for Different Kinds of Freedoms, by Selected Variables, 1974 (\%)

\begin{tabular}{|c|c|c|c|c|c|}
\hline Support for Freedom of... & Press & Religion & $\begin{array}{c}\text { Trade } \\
\text { Unions }\end{array}$ & $\begin{array}{c}\text { Political } \\
\text { Parties } \\
\end{array}$ & $\mathrm{N}$ \\
\hline \multicolumn{6}{|l|}{ Gender } \\
\hline Male & 82 & 77 & 66 & 43 & 1,969 \\
\hline Female & 68 & 67 & 52 & 32 & 2,431 \\
\hline \multicolumn{6}{|l|}{ Size of Community } \\
\hline Less than 2,000 & 67 & 64 & 50 & 33 & 1,006 \\
\hline More than 100,000 & 85 & 84 & 70 & 47 & 855 \\
\hline \multicolumn{6}{|l|}{ Age } \\
\hline 15 to 19 & 79 & 77 & 71 & 47 & 559 \\
\hline 20 to 24 & 85 & 81 & 71 & 52 & 491 \\
\hline 50 to 54 & 75 & 71 & 54 & 29 & 403 \\
\hline Over 54 & 65 & 63 & 49 & 28 & 806 \\
\hline \multicolumn{6}{|l|}{ Education } \\
\hline Elementary & 70 & 67 & 53 & 31 & 2,597 \\
\hline University & 89 & 84 & 72 & 59 & 225 \\
\hline \multicolumn{6}{|l|}{ Subjective Social Class } \\
\hline Upper and Upper-Middle & 86 & 84 & 71 & 56 & 231 \\
\hline Middle & 82 & 79 & 67 & 46 & 1,630 \\
\hline Working, Poor & 65 & 63 & 49 & 28 & 1,631 \\
\hline Overall Population & 74 & 71 & 58 & 37 & 4,399 \\
\hline
\end{tabular}

Source: Adapted from Gómez-Reino, Orizo and Vila (1976, 1191-96) 
Table 4

How Readers of Three Major Newspapers

Voted in $1993(\%)$

\begin{tabular}{lrrr}
\hline Newspaper Read Most Frequently & El País & El Mundo \\
\hline & & & \\
Voted for PSOE & 36 & 13 & 10 \\
Voted for PP & 14 & 74 & 38 \\
Voted for IU & 24 & 5 & 21 \\
Voted for Other Party & 7 & 5 & 2 \\
Did not vote & 19 & 5 \\
\hline
\end{tabular}

Source: 1993 Spanish CNEP survey

Table 5

Opinions of Readers of Three Major Newspapers

Newspaper Read Most Frequently

El País $\quad$ ABC $\quad$ El Mundo

Believe the government wastes

a large amount [gran parte]

of the taxpayers' money

Believe that there is much

$\begin{array}{llll}\text { corruption in Spanish public life } & 34 & 58 & 55\end{array}$

Believe PSOE is more corrupt

than the other parties

$28 \quad 42 \quad 60$

Believe that Felipe González

is "honest" [honrado]

$66 \quad 32$

$32 \quad 26$

Source: 1993 Spanish CNEP survey

Table 6

The Balance of Positive and Negative Evaluative Comments About Political Parties, by Network

Net Evaluative Comments Towards

PSOE PP $\quad$ Overall $^{2}$

\section{Public Television}

TVE-1

$-0.2$

Telemadrid

$-5.3$

$-4.4$

$-5.2$

+4.2 PSOE

Private Television

Tele 5

$-5.5$

Antena 3

$-2.4$

Canal+

$\begin{array}{lll}-3.2 & +2.3 & \mathrm{PP} \\ -2.1 & +0.3 & \mathrm{PP} \\ -4.5 & +0.7 & \mathrm{PP}\end{array}$

${ }^{1}$ This figure was calculated by subtracting all of the negative evaluative statements about each party on each network from the total of positive evaluative statements about that party, then standardizing the figure by dividing the resulting figure by the total number of evaluative statements towards both the PSOE and PP which appeared on news broadcasts by that network.

${ }^{2}$ This figure is produced by subtracting the absolute value of the net of evaluative statements about the less favored party from the absolute value of the net of such assessments regarding the more favored party.

Source: 1993 Spanish CNEP media content analysis (see Díez Nicolás and Semetko, 1995) 
Table 7

Frequency with which Politics Followed Through... (\%)

\begin{tabular}{lcc}
\hline & Pre-Election & Post-Election \\
Medium First Item & & Third Item $^{3}$ \\
\hline
\end{tabular}

Magazines (once/week

or more)

week or more)

Second Item ${ }^{2}$

Radio (three times/

week or more)

Television (three times/

week or more)

$\begin{array}{rrr}13 & 3 & 5 \\ 32 & 28 & 27 \\ 47 & 29 & 28 \\ 79 & 73 & 83\end{array}$

${ }^{1}$ This item asked respondents, "Could you tell me how frequently you follow political information through... [newspapers, general-information magazines, television, and radio]: Every day or almost every day, 3 or 4 days a week, 1 or 2 days a week, less frequently, or never or almost never".

${ }^{2}$ This item was nearly identical to the preceding question, except that it referred specifically to the election campaign that had just ended: "During the election campaign, how frequently did you follow political information through...[newspapers...] [etc.]".

${ }^{3}$ Data in this column summarize responses to probes (asking how many days per week, or, in the case of news magazines, how many days during the campaign) which followed the following questions: "During the past election campaign, which newspaper [or news magazine] did you read the most?"; "During the past election campaign, did you listen to information bulletins or news broadcasts in general on a radio station?", and "What is the name of the broadcast network on which you heard the news?; and "During the past election campaign, did you watch the news on television," and "Can you tell me the name of the television network on which this news appeared?"

Source: 1993 Spanish CNEP survey

Table 8

"Which Medium is the Most..." (\%)

\begin{tabular}{lccc}
\hline Medium & Credible & Informative & $\begin{array}{c}\text { Easy to } \\
\text { Understand }\end{array}$ \\
\hline Magazines & 1 & 1 & 1 \\
Newspapers & 17 & 20 & 8 \\
Radio & 27 & 27 & 19 \\
Television & 33 & 44 & 64 \\
None of the above & 16 & 2 & 3 \\
\hline
\end{tabular}

Source: 1993 Spanish CNEP survey 


\section{NOTES}

1. The Comparative National Elections Project involves teams of researchers who utilized a "common core" of questionnaire items in studies of nationwide elections in Bulgaria, Chile, Germany, Great Britain, Greece, Hong Kong, Hungary, Italy, Japan, Chile, the United States and Uruguay. The Spanish study (under the direction of José Ramón Montero, Richard Gunther, José María Maravall, Ludolfo Paramio Francisco Llera and Francesc Pallarès) involves analysis of data derived from a survey of the attitudes, social characteristics and electoral behavior of a sample of 1,440 Spanish citizens, supplemented by oversamples of the Basque and Catalan regions and by a "snowball" sample of 500 friends and family of the primary respondent, as well as analysis of data derived from a detailed coding of all coverage of the campaign by the print and broadcasting media. This panel survey was carried out in two waves by DATA, S.A., one prior to the start of the 1993 election campaign, the other immediately after the election. The authors wish to acknowledge the generous financial support from the Comisión Interministerial de Ciencia y Tecnología which made this survey possible, as well as the extraordinarily important collaboration of Juan Díez Nicolás and Holli Semetko, who carried out the coding of television broadcasts throughout the campaign.

2. Reports on the Madrid stock market, for example, were sometimes suppressed on the ground that they were "depressing". On many occasions, newspaper articles were suppressed that were based exclusively on information published in official government publications (See Sinova 1989a, especially 77-82).

3. The 1964 survey was conducted by the Instituto de la Opinión Pública (IOP) in July, based on a sample of 1,408 Madrid residents.

4. Indeed, Fraga regarded his reform as a "third way", between the press freedoms of most Western countries and the old system of control first adopted in 1938 (Terrón 1981, 188). Between 1966 and the death of Franco in 1975, the application of the Ley Fraga served as the legal framework for the filing of 1,275 legal actions against publishers and the imposition of 405 formal sanctions, most of which were directed against newspapers and magazines published in Madrid and Barcelona. Initially, these sanctions were related to publication of sexual materials (all forms of nudity were banned from movies and published photographs, while all forms of cinematic violence were cheerfully allowed by the regime's censors), but they were later extended to criticisms of the regime or expressions of support for protest demonstrations against the Franco dictatorship (Terrón 1981, 202-10).

5. Circulation of general information magazines (of which there were eight in 1974) was far smaller than women's and sports magazines, whose weekly circulation totalled over two million (Wert 1976, 111-6; de Bergareche, et al, 1976, 1068-9; and González Seara 1972, 777-8).

6. For a relatively brief period, from the end of the civil war until about 1943, the regime had some totalitarian aspirations. But the extraordinary importance of the Catholic church for both domestic and international legitimation of the regime, the impending defeat of the Axis powers, the drastic down-grading of the Falange within the franquist coalition, the lack of social-revolutionary aspirations of General Franco, and the absence of any consensus within the franquist elite concerning a regime ideology led to the abandonment of all such aspirations and the development of the regime as a quintessentially authoritarian system.

7. In the 1996 parliamentary election, all extreme right-wing parties combined received just 17,000 votes, or .02 percent of all votes cast.

8. Source: Spanish CNEP survey.

9. The retirement from politics of General De Gaulle, for example, gave journalists an opportunity to make somewhat veiled allusions to the disappearance from power of Generalísimo Franco. A few years later, the coup and onset of the democratization process in Portugal were used by newspapers as pretexts for calling for the replacement of franquismo by a democratic regime.

10. An example of this inconsistency was that most Spaniards in 1973 favored some sort of democratic elections, but only 37 percent of those polled at that time favored "freedom of association for political parties" (i.e., the legalization of competitive parties). Nonetheless, just four years later nearly 79 percent of Spaniards were casting ballots for one party or another in competitive elections.

11. It is interesting to note that this key step in the establishment of democracy was badly misinterpreted by the independent and opposition press. The most famous example of this misunderstanding is the oft-cited article by Ricardo de la Cierva in El País, published on the day 
after Suárez's appointment, titled "What a Mistake! What an Immense Mistake!"

12. These functions have been variously described as those of a "resonance chamber" for the voices of political change (Sunkel 1994, 163) or of a "paper parliament" for the presentation and discussion of political alternatives (Montabes 1994).

13. "Liberal" in the European sense. In the misleading American terminology, this newspaper was liberal on social issues and "conservative" on economic matters.

14. In the case of Informaciones, this was the product not only of the entry of new dailies into the market, but also of the more widespread crisis confronting afternoon newspapers everywhere.

15. See Montabes $(1994,57)$ for the lament of the editor of Triunfo, one of the news magazines which played a significant role during the transition, but which faced, in his view, "Darwinian" extinction in the 1980 s.

16. Sources for circulation data: Anuario El País 1988, 216; and Anuario El País 1995, 210.

17. Sources: Spanish data from the October/November Estudio General de Medios, based on 13,285 interviews nationwide; West European data from Zenith Media Worldwide, 1994.

18. In 1991, a new newspaper, Claro, was launched with the stated intention of appealing "to those readers who do not read". A joint enterprise of the Prensa Española (publishers of $A B C$ ) and the Axel Springer group of Germany, the paper survived only four months before disappearing (Edo 1994, 133-7).

19. Among the more politically significant of these regional papers are: in Catalonia, the high-quality, centrist Catalan daily, La Vanguardia, El Periódico, and the more aggressively Catalan nationalist Avui; in Galicia, the moderately conservative La Voz de Galicia; and in Euskadi, the moderately conservative El Correo Español-El Diario Vasco and a plethora of dailies reflecting the political fragmentation of the regional party system existed, including the PNV-owned Deia, and the proETA, pro-Herri Batasuna Egin (Coca and Martínez 1993).

20. In 1994, El País reported an average daily readership of 1.5 million, ABC and El Mundo both about one million, and Diario 16 about 400,000 (as reported in the Estudio General de Medios, a regular survey of the general public's reading, viewing and listening habits). In terms of daily sales, El País averaged over 400,000 per day, as compared with 322,000 for ABC and 269,000 for El Mundo (El País, June 16, 1995, 39). These shares of the reading audience remained stable over the following five years, with one significant exception. The most recent survey (for 1997) indicates that El País had approximately 1,572,000 daily readers, $A B C$ had 952,000, and El Mundo 926,000. This survey also indicated that circulation figures for these three dailies had remained relatively stable, with El País selling about 440,000 copies each day, $A B C$ with 300,000 daily sales, and El Mundo having an average circulation of 285,000 . The major change over this period has been the collapse of Diario 16, whose readership has fallen below the 100,000 level -a decline of over 75 percent in just four years. (Source: Oficina de Justificación de la Difusión).

21. A May 1993 Demoscopia/El País survey directed by José Ignacio Wert included interviews with over 30,000 Spanish citizens, creating a data base large enough to include 1,524 regular readers of El País, 712 of $A B C$, and 403 of El Mundo. A comparison of data derived from that survey reveals that our much smaller CNEP sample was remarkably representative, as the presentation of data later in this chapter will reveal.

22. Using a coding scheme developed by the German CNEP team, all of the news articles dealing with the campaign published on randomly selected days during the campaign were assessed according to 95 different criteria. A total of 131 articles were coded in this manner. Sixty percent of all of the articles appearing in El País and 58 percent of those appearing $A B C$ were classified as including no evaluative statements or biases. But of those perceived as including biased evaluative statements, the PSOE was regarded as being more favorably treated by El País, and the PP was favored by $A B C$. The mean score of all evaluative comments (with highly negative comments scored as 1 and highly favorable statements as 7) regarding the PSOE was 4.3 in El País (somewhat positive) and 3.0 in $A B C$ (somewhat negative), while the PP received mean evaluative scores of 3.4 in El País and 4.7 in $A B C$. The authors wish to express their heartfelt thanks to Ms. Dheer for volunteering her services in this project.

23. El Mundo played a leading role in uncovering evidence of the involvement of high-ranking Interior ministry officials in financing and organizing state-terrorist activities against ETA (the Basque 
terrorist organization) by the so-called GAL. In 1998, after a very complicated investigation, the Supreme Court found José Barrionuevo, Minister of Interior from 1982 to 1986, and Rafael Vera, Deputy Minister for Security, among other high-ranking officials guilty of kidnapping a Basque citizen living in France in 1983. They were sentenced to ten years in prison, although the government, following a recommendation of the Supreme Court, partially pardoned them and released them from jail three months later.

24. As El Mundo's most popular cartoonist stated in explaining his resignation from the newspaper, "Everything is now oriented towards [reporting on] corruption. I think that this kind of news should be reported, but it is really not affecting the average Spaniard to this degree... This newspaper is not balanced, ideologically speaking". (Statements by Antonio Fraguas, reported in El País, February 14, 1995, 31). At present, both $E l$ Mundo and $A B C$ indiscriminately mix news coverage and editorial comment critical of the government (see statements by Luis Carandell and Soledad Gallego-Díaz, in Santos 1995, 163). El País was also guilty of this practice under the UCD governments, but largely (and not surprisingly) desisted after the PSOE came to power. (Also see Roca 1989, 97-8; and Santos 1995, 187-208).

25. The reader should be cautioned that, because of the extremely low level of newspaper readership in Spain, the number of cases upon which the following analyses are based is low: there were only 95 regular readers of El País among our 1,448 survey respondents, 42 regular readers of El Mundo, and $38 A B C$ readers. We are well aware of questions that may be raised concerning sample size and representativeness. Thus, we have taken care to present levels of statistical significance of our findings, whenever relevant, and have couched our conclusions in very cautious language. We should also note that our data are perfectly consistent with the results of the Demoscopia/El País survey of newspaper readership among a nationwide sample of 30,000 Spaniards: the mean selfplacements of El País readers in the Demoscopia survey was 3.8 -exactly the same as in our survey; Demoscopia's El Mundo readers were located at 4.2 (vs. our 4.6); and $A B C$ readers were 5.6 and 6.1, respectively.

26. For example, among the 1,524 regular El País readers polled by Demoscopia in May 1993, 46 stated that they intended to vote for or were sympathetic towards the PSOE, 10 percent for the PP, and 16 percent for IU; 23 percent of $A B C$ readers were attitudinally disposed to vote for the PSOE, 52 percent for the PP and 4 percent for IU; and only 11 percent of El Mundo readers included in the Demoscopia sample favored the PSOE, while 26 percent were predisposed to support the PP and 22 percent IU.

27. While virtually everyone can speak Spanish, about 41 percent of Spaniards also use Catalan, Gallego, Basque, Valenciano, Alicantí, Mallorquín, Menorquín or Ibizenco as a first or second language (Linz 1985).

28. Reversing a decline which occurred under the Franco regime, by 1994, 74 percent of the population of Catalonia were able to speak catalan, and 22 percent more understand it. Only 4 percent say they do not understand it. Among Basques, these same figures are 31 percent, 15 percent, and 54 percent, respectively (See Siguán 1994, 19). This increase in knowledge of the regional language is particularly striking in the Catalan case. In 1981 (at the start of what the regional government calls its "linguistic normalization" program), 80 percent of those in the region said that they could understand Catalan. By 1993, that figure had risen to 96 percent of the population. This increase was particularly pronounced among those born in other parts of Spain who migrated to the region: from 65 percent in 1981 to 88 percent twelve years later.

29. This process is different from that which took place in France under the first "cohabitation" government under Jacques Chirac. In France, part of the public television system was simply transferred to the private sector. The González government, in contrast, maintained the existing two state channels, but allowed for the creation of new private-sector competitors. Hence, the Spanish process was not really one of "privatization", in the strict sense of that term.

30. These include the English-language CNN, NBC's international channel and The Sky Channel, Mexico's Televisa, the French Tele 5, Italy's RAI and German-language DSF.

31. The source for these television-audience estimates is Anuario El País 1995, 220.

32. We are greatly indebted to Holli Semetko and Juan Díez-Nicolás, who are undertaking an exhaustive analysis of the content of news broadcasts during the 1993 campaign. They have generously made available to us data sets based upon the exhaustive coding of tapes of those broadcasts. For a preliminary report of their findings, see Díez Nicolás and Semetko 1995. 
33. During the official campaign period, broadcasts by the TVE network are subjected to careful scrutiny by an inter-party oversight commission in order to encourage fairness in coverage by the public stations.

34. Spokespersons for the governing PSOE spoke for 3,062 seconds during the pre-campaign broadcasts coded by Díez Nicolás and Semetko (1995), as compared with 2,858 seconds for all opposition-party leaders combined. During the official campaign, PSOE leaders spoke for a total of 6,040 seconds, compared with 8,821 seconds for the opposition. (Calculated from data presented in Table 10 of the Díez Nicolás and Semetko piece. It should be noted that, although they base their analysis on the same data that they made available to us, we reach somewhat different conclusions).

35. It should be noted that Díez Nicolás and Semetko reach somewhat different conclusions, largely in the direction of perceiving greater pro-PSOE bias than does our analysis. These differences are due to the fact that their estimates of bias are based upon analysis of only the first (out of a possible total of five) evaluative statements made during the news article, while our analysis is based on all such evaluative statements, up to the maximum of five per article which were coded.

36. See data based on the American CNEP content analysis and survey reported in Beck, Dalton and Huckfeldt 1995). Of those polled in the American survey $(n=1,290), 28$ percent said that the television media favored Clinton in the 1992 campaign, while only 3.5 said that Bush was favored by this medium.

37. While the American CNEP did not include a comparable measure, the American co-author of this chapter estimates that American television news has a much lower public-policy-relevant content.

38. Among those regular television news viewers on the left (who placed themselves at positions 1, 2, 3 or 4 on the left-right scale), 82 percent followed the news on TVE 1 or Tele 5, and only 18 percent watched Antena 3 news broadcasts. Among those on the right (7, 8, 9 or 10 on the left-right scale), 34 percent watched Antena 3, and 66 percent followed the news on the still-dominant TVE 1 or Tele 5. Another study, using a different methodology (logistic regression analysis) confirms our findings about the significant but relatively modest impact of media bias, after the effects of other variables have been taken into consideration. See Belén Barreiro and Ignacio Sánchez Cuenca, "Análisis del cambio de voto hacia el PSOE en las elecciones de 1993", Revista Española de Investigaciones Sociológicas, 82, 1998, 191-211.

39. Indeed, empirical evidence supports this assertion. One study (Luca Ricolfi, "Politics and Mass Media in Italy", West European Politics, 20, 1997, 135-156) estimated that the combined electoral impact of the three RAI networks (which were, comparatively speaking, relatively muted in their political biases) "explained" about 5 percent of the aggregate vote, while the three channels of Berlusconi's Fininvest (which were much more blatant in their partisan bias) accounted for about 13 percent of the vote. With regard to vote shifts, the impact of exposure to the campaign through RAI was minimal, while Berlusconi's channels led to a shift of 4 percent from the PDS to the center-right coalition.

40. It should be noted that advertising for political parties and candidates is permitted on private radio networks and newspapers, while the public radio networks are subject to the same controls as public television.

41. The Junta Electoral Central (JEC) is composed of eight Supreme Court justices (selected by lottery) and five professors of political science or constitutional law nominated by political parties with parliamentary representation. The strong presence of prestigious and impartial jurists on the JEC (rather than partisan politicians, as in many countries) substantially reinforces its ability to guarantee fairness and balance in the conduct of election campaigns.

42. Another measure of this phenomenon can be seen in the increasing domination of news coverage by the top leader of each party, at the expense of other party candidates. During the 1993 campaign, 121 our of 189 references in news broadcasts regarding PP elites referred to Aznar; 85 of 150 references to IU candidates focused on the leader of that coalition Julio Anguita; and 66 of 87 references to CDS candidates dealt with party leader Rafael Calvo Ortega. The domination of electoral politics by the "presidential" candidates has reached such an extent that virtually all of the television news coverage of the final days of the 1995 regional and municipal election campaign focused on the national leaders of each respective party. The actual candidates for the offices at stake (mayors, presidents of regional governments) were virtually absent from the television screens, and purely local issues were almost never mentioned. Instead, these local elections were portrayed as a referendum on the PSOE national government. (For a full general statement of the "presidentialization" thesis, see Bean and Mughan 1989). 
43. This poll of 2,500 Spanish citizens was conducted by the Centro de Investigaciones Sociológicas between May 16 and 19. The results were leaked to and published in Diario 16 on May 26, 1993. For similar data concerning vote intention at various points during the campaign, see Díez Nicolás and Semetko, 1995.

44. The detailed, multivariate analysis undertaken by Barreiro and Sánchez Cuenca $(1998,205)$ confirms our findings about the decisive impact of this debate on the outcome of the 1993 election.

45. As characterized by a journalist, "You grab anything that comes along, any rumor, you throw it out through the radio, and there is no consistency at all. What sells best is to brand as a jackass the prime minister, the Governor of the Bank of Spain, or anybody else that you can use as a punching bag... Talk shows are part of a plan of attack against the [PSOE] government, and the closer you get to election day, the more virulent they become" (See Santos 1995, 141-2).

46. COPE was perceived as favoring the PP by 96 percent of its listeners who perceived bias $(n=23)$, Onda Cero $(n=17)$ by 88 percent, and Antena $3(n=6)$ by 67 percent. Among Radio Nacional listeners who perceived bias $(n=12), 83$ percent thought that RNE favored the PSOE, as did 82 percent of SER listeners who perceived bias $(n=11)$. Expressed as percentages of all regular listeners to these networks, these figures are reduced to the following, more modest levels: those who perceived pro PP bias included 29 percent of all COPE listeners $(n=76), 23$ percent of the total Onda Cero audience $(\mathrm{n}=65)$, and 9 percent of regular Antena 3 listeners; 10 percent of all SER listeners thought that their network was pro PSOE, as did 9 percent of the regular RNE audience. It should be noted that COPE and Onda Cero were regarded as much more biased than the other radio networks.

47. These empirical findings are very similar to those derived from the massive Demoscopia survey of 30,000 Spaniards, undertaken just prior to the 1993 election.

48. Among regular radio listeners on the left (positions 1, 2, 3 or 4 on the left-right scale), 71 percent listened to RNE or SER, while 72 percent of radio listeners on the right $(7,8,9$ or 10) preferred COPE, Antena 3 or Onda Cero. We should recall that among television viewers on the right, although they were much more predisposed to follow Antena 3 news broadcasts than those of TVE 1 or Tele 5, fully 64 percent watched the news regularly on those generally pro-PSOE channels.

49. These individuals were the Minister of Finance and Economics, the leader of the Comisiones Obreras (the trade union that is closest to the Spanish Communist Party), the speaker of the Congress of Deputies, and the president of the CEOE (the peak association of big-business employers). Scores on this "information test" ranged from 0 to 4 , with one point given for each individual correctly identified.

50. As Ferejohn has observed, "Because information acquisition is costly, individuals will generally not choose to be completely informed about anything" (Ferejohn 1990, 14). Our argument shares with "rational choice" scholars in American politics this concern with the costs of information seeking, but comes to a different conclusion. Americanists in this school (see Ferejohn and Kuklinski 1990, and Popkin 1991) argue that because of the cost of information-seeking, most voters will choose to be well informed about very few issues (if any). While we would not disagree with this argument, we focus our attention on the significantly different "costs" of information seeking through different communications media.

51. In an analysis of the 1990 German elections, Rüdiger Schmitt-Beck finds strong evidence that the "bandwagon" effect of the campaign was much more pronounced among "independents" and less sophisticated voters (See "Mass Media, the Electorate, and the bandwagon: A Study of Communication Effects on Vote Choice in Germany", International Journal of Public Opinion Research, 8, 1996, 265-291).

\section{REFERENCES}

ABELlÁN, Manuel L.: Censura y creación literaria en España (1939-1976). Barcelona, Ediciones Península, 1989.

AGUILAR, Miguel Angel: El vértigo de la prensa. Madrid, Editorial Mezquita, 1982.

ALFÉREZ, Antonio: El cuarto poder en España. Barcelona, Plaza y Janés, 1986. 
ARANGO, Joaquín; DÍEZ, Miguel: “6-J: el sentido de una elección”, Claves de la Razón Práctica, 36/1993, p. $10-18$.

BARRERA, Carlos: Periodismo y franquismo. De la censura a la apertura. Pamplona, Ediciones Internacionales Universitarias, 1995.

BEAN, Clive; MUGHAN, Anthony: "Leadership Effects in Parliamentary Elections in Australia and Great Britain”, American Political Science Review, 83/1989, p. 1165-1179.

BENEYTO, Juan: "Los diarios impresos españoles", Revista Española de la Opinión Pública, 1/1965, p. 926.

BECK, Paul Allen; RUSSELL, J. Dalton; HUCKFELDT, Robert: "Political Intermediation in a Multi-Message Environment: The Case of the United States". Paper presented at the meeting of the Comparative National Election Project, Columbus, Ohio, March 12-14/1995.

CEBRIÁN, Juan Luis: La prensa y la calle. Madrid, Editorial Nuestra Cultura, 1980.

COCA, César; MARTÍNEZ, Florencio (eds.): Los medios de comunicación en el País Vasco. Bilbao, Universidad del País Vasco, 1993.

DE BERGARECHE, Isabel, et al.: "Consumo, trabajo y ocio en el desarrollo económico", in Estudios sociológicos sobre la situación social de España, 1975. Madrid, Euroamérica, 1976.

DÍAZ NOSTY, Bernardo: Comunicación social. Tendencias 1994. Madrid, Fundesco, 1994.

DÍEZ NICOLÁS, Juan; SEMETKO, Holli A.: "La televisión y las elecciones de 1993”, in MUÑOZ ALONSO, Alejandro; ROSPIR, Juan Ignacio (eds.): Comunicación política. Madrid, Editorial Universitas, ROSPIR, 1995.

EDO, Concha: La crisis de la prensa diaria. La línea editorial y la trayectoria de los periódicos de Madrid. Barcelona, Editorial Ariel, 1994.

GARCÍA ESCUDERO, Juan Manuel: "Ya". Medio siglo de historia (1935-1985). Madrid, Biblioteca de Autores Cristianos, 1984.

GAITÁN, Juan Antonio: "La opinión del diario El País en la transición española", Revista Española de Investigaciones Sociológicas, 57/1992, p. 149-164.

GÓMEZ-REINO, Manuel; ORIZO, Francisco A.; VILA, Darío: "Sociología política”, in Fundación FOESSA: Estudios sociológicos sobre la situación social de España, 1975. Madrid, Euroamérica, 1976.

GÓMEZ-REINO, Manuel; ORIZO, Francisco A.; VILA, Darío: “Los medios de comunicación de masas y la formación de la opinión pública”, in DEL CAMPO, Salustiano (ed.): La España de los años 70, vol. I, La sociedad. Madrid, Editorial Moneda y Crédito, 1972.

GUNTHER, Richard: Culture and Politics in Spain. Politics and Culture Series, Samuel H. Barnes Series Editor. (Ann Arbor, Center for Political Studies, Institute for Social Research, University of Michigan), 1988.

GUNTHER, Richard: "Spain: The Very Model of Modern Elite Settlement”, in HIGLEY, John; GUNTHER, R. (eds.): Elites and Democratic Consolidation in Latin America and Southern Europe. Cambridge, Cambridge University Press, 1992a.

GUNTHER, Richard: Política y cultura en España. Madrid, Centro de Estudios Constitucionales, 1992 b.

GUNTHER, Richard: "The Collapse of the UCD" (Forthcoming), in GUNTHER, Richard; LINZ, Juan J.; MONTERO, José Ramón (eds.): The Changing Roles of Political Parties in Contemporary Democracies.

GUNTHER, Richard, SANI, Giacomo; SHABAD, Goldie: Spain After Franco. The Making of a Competitive Party System. Berkeley, University of California Press, 1986.

GUNTHER, Richard; MONTERO, José Ramón: Los anclajes del partidismo, in DEL CASTILLO, Pilar (ed.), 1994. 
GUNTHER, Richard; MONTERO, José Ramón; TORCAL, Mariano: “Anti-party Sentiments in Europe: A Preliminary Exploration”. Paper presented at the Symposium on Political Parties: Changing Roles in Contemporary Democracies, Instituto Juan March, Madrid, 1994.

GUNTHER, Richard; PUHLE, Hans-Jürgen; DIAMANDOUROS, Nikiforos (eds.): "Introduction", in GUNTHER, R.; DIAMANDOUROS, N.; PUHLE, H.J.: The Politics of Democratic Consolidation: Southern Europe in Comparative Perspective. Baltimore, The Johns Hopkins University Press, 1995.

HERMET, Guy: Los católicos en la España franquista. Madrid, Centro de Investigaciones Scoiológicas, 1985.

HUERTAS, Fernando (ed.): Televisión y política. Madrid, Editorial Complutense, 1994.

IGLESIAS, Francisco: Historia de una empresa periodística: Prensa Española, editora de “ABC” $y$ “Blanco y Negro”(1891-1978). Madrid, Prensa Española, 1980.

IMBERT, Gérard: Le discours du journal. A propos de "El País”. Pour une approach socio-sémiotique du discours de la presse. Paris, Centre Nationale de la Recherche Scientifique, 1988.

IOP [Instituto de la Opinión Pública]: Estudios sobre los medios de comunicación en España. Madrid, Instituto de la Opinión Pública, 1964.

IOP [Instituto de la Opinión Pública]: "Los medios de comunicación de masas en España”, Revista Española de la Opinión Pública, 0/1965a, p. 145-151.

IOP [Instituto de la Opinión Pública]: "Encuesta sobre medios de comunicación de masas en España: prensa, radio, televisión, cine, teatro y libros", Revista Española de la Opinión Pública, 1/1965b., p. 181-296.

IOP [Instituto de la Opinión Pública]: "Encuesta sobre la lectura de prensa diaria", Revista Española de la Opinión Pública, 7/1967, p. 247-283.

IOP [Instituto de la Opinión Pública]: "Encuesta sobre la radio", Revista Española de la Opinión Pública, 19/1970, p. 167-216.

IOP [Instituto de la Opinión Pública]: "Informe sobre los medios de comunicación de masas en España”, Revista Española de la Opinión Pública, 39/1975a, p. 297-329.

IOP [Instituto de la Opinión Pública]: “Informe sobre los medios de comunicación en España”, Revista Española de la Opinión Pública, 40-41/1975b, p. 263-284.

IOP [Instituto de la Opinión Pública]: "Medios de comunicación de masas", Revista Española de la Opinión Pública, 43/1976, p. 399-410.

JIMÉNEZ BLANCO, José et al: La conciencia regional en España. Madrid, Centro de Investigaciones Sociológicas, 1977.

KLAPPER, Joseph T.: Efectos de las comunicaciones de masas. Madrid, Ediciones Aguilar. 1974.

LINZ, Juan J.: "Una teoría del régimen autoritario: el caso de España", in FRAGA, Manuel (ed.): La España de los años setenta, vol. 3, El Estado y la política. Madrid, Editorial Moneda y Crédito, 1974.

LINZ, Juan J.: “Totalitarian and Authoritarian Regimes”, in GREENSTEIN, Fred I.; POLSBY, Nelson W. (eds.): Handbook of Political Science, vol. 3, Macropolitical Theory. Reading, Mass., AddisonWesley, 1975.

LINZ, Juan J.: "The Legacy of Franco and Democracy", in BAIER, Horst; KEPPLINGER, Hans Mathias; REUMANN, Kurt (eds.): Öffentliche Meinung und sozialer Wandel. Westdeutscher Verlag, 1982.

LINZ, Juan J.: "De la crisis de un Estado unitario al Estado de las Autonomías”, in FERNÁNDEZ, Fernando (ed.): La España de las Autonomías. Madrid, Instituto de Estudios de Administración Local, 1985.

LINZ, Juan J. GÓMEZ-REINO, Manuel; ORIZO, Francisco A.; VILA, Darío: Informe sociológico sobre el cambio político en España. Madrid, Euroamérica, 1981. 
LINZ, Juan J.; MONTERO, José Ramón (eds.): Crisis y cambio: electores y partidos en la España de los años ochenta. Madrid, Centro de Estudios Constitucionales, 1986.

LÓPEZ PINA, Antonio; ARANGUREN, Eduardo L.: La cultura política de la España de Franco. Madrid, Taurus, 1976.

LÓPEZ PINTOR, Rafael: "En torno a las conexiones entre opinión pública y decisión política: la actitud de los españoles ante la Comunidad Económica Europea", Revista Española de la Opinión Pública, 37/1974, p. 7-22.

LÓPEZ PINTOR, Rafael: La opinión pública española del franquismo a la democracia. Madrid, Centro de Investigaciones Sociológicas, 1982.

LÓPEZ PINTOR, Rafael; BUCETA, Ricardo: Los españoles de los años 70. Una versión sociológica. Madrid, Editorial Tecnos, 1975.

MARAVAlL, José María: Dictatorship and Political Dissent: Workers and Students in Franco's Spain. London, Tavistock, 1978.

MARAVALL, José María; SANTAMARÍA, Julián: “Transición política y consolidación de la democracia en España”, in TEZANOS, José F.; COTARELO, Ramón; DE BLAS, Andrés (eds.): La transición democrática en España. Madrid, Sistema, 1989.

MARTÍNEZ DE LAS HERAS, Agustín: “Las etapas españolas de la desreglamentación”, in ALVAREZ, Jesús T. (ed.): Historia de los medios de comunicación en España. Periodismo, imagen y publicidad (1900-1990). Barcelona, Editorial Ariel, 1989.

MAXWELL, Kenneth: "Introduction: The Transition to Democracy in Spain and Portugal", in MASSWELL, K. (ed.): The Press and the Rebirth of Iberian Democracy. Westport, Conn., Greenwood Press, 1983.

MILLER, William L.: Media and Voters. The Audience, Content, and Influence of Press and Television at the 1987 General Elections. Oxford, Clarendon Press, 1991.

MONTABES, Juan: La prensa del Estado durante la transición política española. Madrid, Centro de Investigaciones Sociológicas, 1989.

MONTABES, Juan: "Los parlamentos de papel en el caso español”, in FILGUEIRA, Carlos H.; NOHLEN, Dieter (eds.): Prensa y transición democrática. Experiencias recientes en Europa y América Latina. Madrid, Iberoamericana, 1994.

MONTERO, José Ramón: "Las derechas en el sistema de partidos republicano del segundo bienio: algunos datos introductorios", in GARCÍA DELGADO, José L. (ed.): La II República española. Bienio rectificador y Frente Popular, 1934-1936. Madrid, Siglo XXI, 1988.

MONTERO, José Ramón: "Las dimensiones de la secularización: religiosidad y preferencias políticas en España”, in DÍAZ-SALAZAR, Rafael; GINER, Salvador (eds.): Religión y sociedad en España. Madrid, Centro de Investigaciones Sociológicas, 1993.

MONTERO, José Ramón; TORCAL, Mariano: "La cultura política de los españoles: pautas de continuidad y cambio", Sistema, 99/1990, p. 39-74.

MONTERO, José Ramón; GUNTHER, Richard: "Democratic Legitimacy in Spain”. Paper presented at the ???? IPSA World Congress, Berlin, 1994.

MORAL, Félix: La opinión pública española ante Europa y los europeos. Madrid, Centro de Investigaciones Sociológicas, Estudios y Encuestas, 1989.

MULTIGNER, Gilles: "La radio, de 1940 a 1960: ocios y negocios rigurosamente vigilados", in ALVAREZ, Jesús T. (ed.): Historia de los medios de comunicación en España. Periodismo, imagen y publicidad (1900-1990). Barcelona, Editorial Ariel, 1989.

PIZARROSO, Alejandro: "Política informativa: información y propaganda (1939-1966)", in ALVAREZ, Jesús T. (ed.): Historia de los medios de comunicación en España. Periodismo, imagen y publicidad (1900-1990). Barcelona, Editorial Ariel, 1989. 
RANNEY, Austin: Channels of Power. New York, Basic Books, 1983.

SANTOS, Félix: Periodistas. Polanquistas, sindicato del crimen, tertulianos y demás tribus. Madrid, Ediciones Temas de Hoy, 1995.

SIGUÁN, Miguel: Conocimiento y uso de las lenguas en España. (Investigación sobre el conocimiento y uso de las lenguas oficiales en las Comunidades Autónomas bilingües). Madrid, Centro de Investigaciones Sociológicas, Opiniones y Actitudes, 1994.

SINOVA, Justino: La gran mentira. Barcelona: Editorial Planeta, 1983.

SINOVA, Justino: La censura de prensa durante el franquismo (1936-1951). Madrid, Espasa Calpe, 1989a.

SINOVA, Justino: "La dificil evolución de la prensa no estatal”, in ALVAREZ, Jesús T. (ed.): Historia de los medios de comunicación en España. Periodismo, imagen y publicidad (1900-1990). Barcelona, Editorial Ariel, 1989b.

SINOVA, Justino: Un millón de votos. 6-J: la verdadera historia de las elecciones que alumbraron un nuevo orden político en España. Madrid, Ediciones Temas de Hoy, 1993.

SUNKEL, Guillermo: "La prensa en la transición chilena", in FILGUEIRA, Carlos H.; NOHLEN, Dieter (eds.): Prensa y transición democrática. Experiencias recientes en Europa y América Latina. Madrid, Iberoamericana, 1994.

TERRÓN, Javier: La prensa en España durante el régimen de Franco. Un intento de análisis político. Madrid, Centro de Investigaciones Sociológicas, 1981.

TUSELL, Javier: Franco y los católicos. La política interior española entre 1945 y 1957 . Madrid, Alianza Editorial, 1984.

WERT, José Ignacio: "Estructura y pautas de información en la España de hoy”, Revista Española de la Opinión Pública, 43/1976, p. 99-35.

WERT, José Ignacio: Política y medios de comunicación. Madrid, Cuadernos de la Fundación Humanismo y Democracia, 1980.

WERT, José Ignacio: "Los medios de comunicación en la década de la libertad", in Diez años en la vida de los españoles. Barcelona, Plaza y Janés, 1986.

WERT, José Ignacio: "Perspectivas de reforma del régimen electoral: campañas, medios de comunicación y encuestas electorales", in MONTERO, José Ramón; GUNTHER, Richard; WERT, José I.; SANTAMARÍA, Julián; ABAD, Miguel A.: La reforma del régimen electoral. Madrid, Centro de Estudios Constitucionales, 1994.

WERT, José Ignacio; LÓPEZ PINTOR, Rafael; TOHARIA, José Juan: "El regreso de la política. Una primera interpretación de los resultados del 6-J”, Claves de la Razón Práctica, 34/1993, p. 32-42. 